\title{
REVIEW
}

\section{Prospects for captive breeding of poorly known small cetacean species}

\author{
Barbara E. Curry ${ }^{1, *}$, Katherine Ralls ${ }^{2}$, Robert L. Brownell Jr. ${ }^{3}$ \\ ${ }^{1}$ Physiological Ecology and Bioenergetics Laboratory, University of Central Florida, Orlando, Florida 32816, USA \\ ${ }^{2}$ Smithsonian Conservation Biology Institute, National Zoological Park, Washington, DC 20008, USA \\ ${ }^{3}$ Southwest Fisheries Science Center, National Marine Fisheries Service, NOAA, Pacific Grove, California 93950, USA
}

\begin{abstract}
Because of the precarious condition of small cetacean species and subpopulations listed as Endangered or Critically Endangered by the IUCN, use of captive breeding for conservation has been suggested for some of them, and will likely be suggested for others. A successful captive breeding program for a new species cannot be implemented until reliable capture and husbandry techniques have been developed. Techniques for assisted reproduction and reintroduction may also be needed. We review attempts to capture, maintain, and breed poorly known small cetaceans and discuss assisted reproductive technologies (ART) that have been used to enhance captive breeding efforts for other small cetaceans. We conclude that the techniques required for successful captive breeding of most Endangered or Critically Endangered small cetacean species have not been sufficiently developed. Development of these techniques should begin before a species or population is Critically Endangered. In particular, ARTs tend to be species specific, necessitating considerable time, money, and research to develop for each species of concern. Critically Endangered populations cannot afford to lose the individuals needed for technique development. The fairly large captive population sizes necessary (to avoid loss of genetic diversity, inbreeding, and genetic adaptation to captivity), limited space available in aquariums, and high costs of captive breeding and reintroduction programs make it unlikely that captive breeding will play a major role in the conservation of most small cetaceans. The substantive conservation measures needed to prevent extinction of Critically Endangered small cetaceans is reduction or elimination of their primary threats, which are usually by-catch and habitat loss.
\end{abstract}

KEY WORDS: Breeding program · Ex situ conservation $\cdot$ Live capture $\cdot$ Acclimation $\cdot$ Assisted reproductive technologies · ART · Artificial insemination · Dolphin · Conservation threats

\section{INTRODUCTION}

Captive breeding and reintroduction have played a pivotal role in the recovery of some terrestrial species such as the Arabian oryx Oryx leucoryx (Stanley Price 1989), the golden lion tamarin Leontopithecus rosalia (Kleiman \& Rylands 2002), the California condor Gymnogyps californianus (Ralls \& Ballou 2004), and the black-footed ferret Mustela nigripes (Wisely et al. 2003). However, many attempts to develop captive breeding programs for other terrestrial species have failed because the species has not survived or reproduced well in captivity (Lees \& Wilcken 2009).

The impending extinction of the Chinese river dolphin, the baiji Lipotes vexillifer, prompted an examination of the usefulness of captive or semi-captive breeding in a reserve as a means of conserving it (Perrin et al. 1989, Ralls 1989, Ridgway et al. 1989, Braulik 
et al. 2005), but such a program was not implemented. Captive breeding proved difficult, and multiple anthropogenic impacts soon led to the extinction of this species (Dudgeon 2005, Reeves \& Gales 2006, Wang et al. 2006, Turvey et al. 2007, Turvey 2008). The suggestion to use captive breeding as a means of conserving other Endangered or Critically Endangered small cetacean populations is nonetheless likely to emerge repeatedly, because it has contributed to the recovery of some terrestrial species.

Although captive breeding has not played a major role in the conservation of any cetacean, there have been numerous captive births of the species most commonly kept in captivity (e.g. common bottlenose dolphins Tursiops truncatus, Indo-Pacific bottlenose dolphins T. aduncus, and killer whales Orcinus orca), and attempts are being made at captive propagation of less frequently held small cetaceans such as the Yangtze finless porpoise Neophocaena asiaeorientalis asiaeorientalis (Wang et al. 2005, 2010, Wang 2009, Jefferson \& Wang 2011).

Assisted reproductive technology (ART) for enhancement of captive breeding in cetaceans has been developed for several commonly held species, and refinement of the techniques involved has contributed significantly to scientific knowledge of cetacean reproductive physiology and improved management of captive populations (Robeck et al. 1994, 2008, O'Brien \& Robeck 2010a).

In recent decades the magnitude and complexities of human impacts on ecosystem function have emerged as a major challenge to scientists and conservationists working to sustain biodiversity and habitat on local and global scales (Margules \& Pressey 2000, Hooper et al. 2005, Knight et al. 2006). It is becoming evident that conservation in situ will require ongoing spatial management in the form of parks and reserves and rigorous habitat protection (Lee \& Jetz 2008, Visconti et al. 2010). In addition, there is increasing recognition that zoological institutions have limited animal-carrying capacity and propagation ex situ must be much more closely managed (Russello \& Amato 2007, Conway 2010). Snyder et al. $(1996,1997)$ provided a convincing rationale (including the possibility of disease among the founders of the population, prohibitively high costs of long-term maintenance, and the difficulties of reintroduction) that captive breeding can play a legitimate role in the recovery of only a limited number of endangered species and should be adopted only when feasible alternatives are unavailable.

In general, a captive breeding program should not be undertaken for conservation of a wild population if numbers of free-ranging individuals are insufficient for the population as a whole to withstand the removal of some individuals. The International Union for the Conservation of Nature (IUCN) has technical guidelines for management of ex situ populations as a method of conservation (IUCN 2012). These provide practical guidance for determining when ex situ management is warranted for a given taxon and for assessing the potential feasibility of ex situ conservation as well as the risks to the wild population. The IUCN guidelines emphasize the need for overall strategic planning for a species to be undertaken as early as possible.

We argue that a captive breeding program for a new species cannot be successfully implemented until reliable techniques have been developed for capture and husbandry of that species. Although there have been many advancements in methodologies for the husbandry, maintenance, and medical care of small cetacean species in recent decades (Brando 2010, Houser et al. 2010, Joseph \& Antrim 2010), risk is inherent to bringing poorly known cetacean species into captivity. There is often a learning process for the housing institution that may come at the price of compromised health and/or mortality of new captives, and some species or individuals may not acclimate well to the captive environment (Walker 1975, Small \& De Master 1995a). Technologies for assisted reproduction and techniques for release or reintroduction into the wild may also need to be developed.

To examine the prospects for using captive breeding to help conserve Endangered or Critically Endangered small cetaceans such as the Asian Ganges and Indus river dolphins (Platanista gangetica gangetica and P. g. minor, respectively), the vaquita Phocoena sinus, and the river-dwelling and marine subpopulations of the Irrawaddy dolphin Orcaella brevirostris (Table 1), we review attempts to capture, maintain, and breed poorly known small cetaceans in captivity. We then discuss the current state of ART for captive cetaceans and the prospects for applying these techniques to other poorly known small cetaceans. Finally, we outline the minimum objectives that would be necessary to initiate a captive breeding program for such species. We hope this paper will provide a starting point for identifying and addressing weaknesses in the potential for successful captive breeding of poorly known small cetaceans, prompting scientists and conservationists to more carefully examine and evaluate the logistical realities and risks of creating captive breeding programs for individual taxa of concern. 
Table 1. Some of the poorly known small cetacean populations listed by the International Union for the Conservation of Nature (IUCN) as Critically Endangered, and the Endangered Ganges and Indus river dolphins whose populations are severely fragmented

\begin{tabular}{|c|c|c|c|c|}
\hline $\begin{array}{l}\text { Species } \\
\text { Subpopulation }\end{array}$ & IUCN status & Native country & $\begin{array}{l}\text { Population } \\
\text { estimate }\end{array}$ & Source \\
\hline \multicolumn{5}{|c|}{ South Asian river dolphin Platanista gangetica } \\
\hline $\begin{array}{l}\text { Ganges river dolphin } \\
P . \text { g. gangetica }\end{array}$ & Endangered & $\begin{array}{l}\text { India, Bangladesh, } \\
\text { Nepal (poss. Bhutan) }\end{array}$ & $<2000-4000$ & $\begin{array}{l}\text { Mohan et al. (1997), } \\
\text { Smith et al. (2004a) }\end{array}$ \\
\hline $\begin{array}{l}\text { Indus river dolphin } \\
\text { P. g. minor }\end{array}$ & Endangered & Pakistan & 965 & Braulik et al. (2004) \\
\hline \multicolumn{5}{|l|}{ Vaquita Phocoena sinus } \\
\hline $\begin{array}{l}\text { Species level: subpop. } \\
\text { not applicable }\end{array}$ & $\begin{array}{l}\text { Critically } \\
\text { Endangered }\end{array}$ & Mexico & 245 & Gerrodette et al. (2011) \\
\hline \multicolumn{5}{|c|}{ Irrawaddy river dolphin Orcaella brevirostris } \\
\hline Ayeyarwady River & $\begin{array}{l}\text { Critically } \\
\text { Endangered }\end{array}$ & Myanmar & 59 & $\begin{array}{l}\text { Smith et al. (1997), } \\
\text { Smith (2004) }\end{array}$ \\
\hline Mahakam River & $\begin{array}{l}\text { Critically } \\
\text { Endangered }\end{array}$ & Indonesia & $67-70$ & $\begin{array}{c}\text { Kreb \& Syachraini (2007) } \\
\text { Jefferson et al. (2008) }\end{array}$ \\
\hline Malampaya Sound & $\begin{array}{l}\text { Critically } \\
\text { Endangered }\end{array}$ & Philippines & 77 & $\begin{array}{l}\text { Smith et al. (2004b), } \\
\text { Smith \& Beasley (2004a) }\end{array}$ \\
\hline Mekong River & $\begin{array}{l}\text { Critically } \\
\text { Endangered }\end{array}$ & $\begin{array}{l}\text { Cambodia, Laos } \\
\text { PDR, Vietnam }\end{array}$ & 69 & Smith \& Beasley (2004b) \\
\hline Songkhla Lake & $\begin{array}{l}\text { Critically } \\
\text { Endangered }\end{array}$ & Thailand & Unknown $^{\mathrm{a}}$ & $\begin{array}{l}\text { Beasley et al. (2002), } \\
\text { Smith \& Beasley (2004c) }\end{array}$ \\
\hline
\end{tabular}

\section{CAPTURE AND TRANSPORT OF SMALL CETACEANS}

Although capture and transport of cetaceans are known to be high-risk procedures, especially for poorly known species, few descriptions of the difficulties of these activities and the often high injury and mortality rates of the animals involved appear in the scientific literature. Small cetaceans such as the harbor porpoise Phocoena phocoena, Dall's porpoise Phocoenoides dalli, common dolphins belonging to the genus Delphinus, and the northern right whale dolphin Lissodelphis borealis have had relatively high mortality rates and short survival times after capture (Walker 1975, Reeves \& Mead 1999, Dima \& Gache 2004). In some instances, this mortality may have been related to stress during capture (Curry 1999, Cowan \& Curry 2008). Van Waerebeek et al. (2008) also have documented the potentially disastrous effects of ill-conceived live-capture endeavors.

Capture and transport conditions vary widely depending on capture location, climate, and characteristics of transportation (vessel, vehicle, or aircraft; ambient temperature control). Duration of transport can be many hours, and conditions are likely to be more difficult in remote or underdeveloped regions where many poorly known small cetacean species occur (e.g. Tas'an \& Leatherwood 1984, Sylvestre 1985, Caldwell et al. 1989, Boede et al. 1998, Bonar et al. 2007).
From the early 1950 s to 1970 s, Amazon river dolphins Inia geoffrensis were captured (mostly with nets), transported over several days, and kept captive in the USA, Europe, and Japan (Brownell 1984, Sylvestre 1985, Caldwell et al. 1989, Tobayama \& Kamiya 1989). No data exist for mortality at the time of capture, but deaths often occurred during transport over long time periods like to the USA (Caldwell et al. 1989). During the 1970 s to 1990 s, this species was captured and held in the Brazilian Amazon (da Silva 1994) and was also captured in the Orinoco River system and transported, for up to $12 \mathrm{~h}$, to be held at the Valencia Aquarium, Venezuela (Boede et al. 1998).

A few small cetacean species have been captured and transported to aquaria in Japan since the 1930s, but good records start in 1963. At least 153 narrowridged finless porpoises Neophocaena asiaeorientalis were captured there between 1963 and 1984 (Kasuya et al. 1984). These porpoises were obtained from incidental catches before 1972, but beginning in 1973 Toba Aquarium captured them directly using seine nets (Kasuya et al. 1984). At least 78 finless porpoises were directly captured for display between 1973 and 1993 (Kasuya et al. 1984, Reeves et al. 1997). Mortality rates during capture have not been commonly reported, and survival rate in captivity is not well known. Aquariums in Japan can replace dead individuals with new ones because it is relatively easy to obtain them from the wild. Live porpoises are cap- 
tured mainly in Ise Bay and the Inland Sea of Japan, although a few were taken near Sendai Bay, Japan (Kasuya et al. 1984, Miyashita et al. 2005).

There are known difficulties with capture and transport of Irrawaddy dolphins, especially in riverine habitat. The drive method was used to capture 20 Irrawaddy dolphins from the Mahakam River, Indonesia, in 1974 and 1978 for transport (12 h) to the Jaya Ancol Oceanarium in Jakarta, and 6 more dolphins were captured in 1984 (Tas'an et al. 1980, Tas'an \& Leatherwood 1984, Wirawan 1989). These captures involved mortality attributed to the stress of capture and transport (Table 2). In addition, Beasley (2002) reported that in 1999, during preparation for intra-aquarium transport activities (from Oasis Sea World, Chantaburi Province, Thailand, to Underwater World, Singapore), 1 of 4 Irrawaddy dolphins died, and the remaining 3 were considered to be 'unstable for transport,' leading to the cancellation of intended transport activities.
Twenty-seven (7 in 2008 and 20 in 2011) Irrawaddy dolphins were recently captured from the coastal waters off Kien Giang (Gulf of Thailand) near Hon Chong, Kien Giang Province, by the Vietnam-Russia Tropical Center for use in 'scientific research and circus performances' (Nguyen et al. 2010, 2012a). Dolphins were kept in a sea-pen and were subsequently transported via helicopter and airplane. Mortality was not reported, but disposition was reported for only 3 animals (Nguyen et al. 2010, 2012b) - 2 adults and 1 immature dolphin were reported to be housed at Dai Nam Wonderland, Binh Duong Province. In June 2011, 4 Irrawaddy dolphins, in addition to the 3 in Binh Duong Province, were widely advertised to have been transported to Vinpearl Land, Nha Trang, Khanh Hoa Province. 1

There have been improvements in capture and transport techniques (e.g. those discussed by Braulik et al. 2005 and Bonar et al. 2007, and used by Wells et al. 2004). These techniques were developed through

Table 2. Orcaella brevirostris. Twenty-six Irrawaddy dolphins captured between 1974 and 1984 from the Mahakam River, Indonesia, for captivity at Jaya Ancol Oceanarium (Tas'an et al. 1980, Wirawan 1989). Date of death and survival time are included if known. Note: Six of 16 individuals with unknown survival times were alive in 1985; 2 remained alive in 1995 (Tas'an et al. 1980, Tas'an \& Leatherwood 1984, Stacey \& Leatherwood 1997, Stacey \& Arnold 1999)

\begin{tabular}{|c|c|c|c|c|c|}
\hline Identification & Sex & $\begin{array}{c}\text { Date } \\
\text { captured }\end{array}$ & $\begin{array}{c}\text { Date of } \\
\text { death }\end{array}$ & $\begin{array}{l}\text { Survival } \\
\text { time }\end{array}$ & Reported condition/pathologies \\
\hline 1 individual & Female & 15 Oct 1974 & Unknown & Unknown & Pregnant_-released after capture \\
\hline 1 individual & Unknown & 15 Oct 1974 & Unknown & Unknown & 'Not fit for transport' — released after capture \\
\hline 74GSA16mOb1 & Female $^{\mathrm{a}}$ & 15 Oct 1974 & Deceased & Unknown & Unknown \\
\hline 74GSAl7mOb2 & Male & 15 Oct 1974 & 4 Nov 1974 & $20 \mathrm{~d}$ & Gastrointestinal ulcers, stress \\
\hline 74GSA18mOb3 & Female & 15 Oct 1974 & 23 Oct 1974 & $10 \mathrm{~d}$ & Gastrointestinal ulcers, stress \\
\hline 74GSA18mOb4 & Male & 15 Oct 1974 & Deceased & Unknown & Unknown \\
\hline 74GSA20mOb5 & Male & 15 Oct 1974 & 2 Jul 1978 & 3 yr $261 \mathrm{~d}$ & Pulmonary infection \\
\hline 74GSA21mOb6 & Female & 15 Oct 1974 & 16 Oct 1974 & $1 \mathrm{~d}$ & Stress \\
\hline 1 individual & Unknown & 24 Sep 1978 & Unknown & Unknown & Unknown-not transported \\
\hline 1 individual & Unknown & 24 Sep 1978 & Unknown & Unknown & Unknown-not transported \\
\hline 74GSA94mOb7 & Male & 24 Sep 1978 & Deceased & Unknown & Unknown \\
\hline 78GSA95mOb8 & Male & 24 Sep 1978 & 17 Jan 1979 & $115 \mathrm{~d}$ & 'Constitutional heart weakness' \\
\hline 78GSA96mOb9 & Male & 24 Sep 1978 & Deceased & Unknown & Unknown \\
\hline 78GSA97mOb10 & Male & 24 Sep 1978 & Deceased & Unknown & Unknown \\
\hline 78GSA98mOb11 & Female & 24 Sep 1978 & Deceased & Unknown & Unknown \\
\hline 78GSA99mOb12 & Male & 24 Sep 1978 & Deceased & Unknown & Unknown \\
\hline 78GSA100mOb13 & Male & 24 Sep 1978 & Deceased & Unknown & Unknown \\
\hline 78GSA111mOb14 & Male & 24 Sep 1978 & Deceased & Unknown & Unknown \\
\hline 78GSA112mOb15 & Male & 24 Sep 1978 & Deceased & Unknown & Unknown \\
\hline 78GSA113mOb16 & Male & 24 Sep 1978 & 24 Oct 1978 & $30 \mathrm{~d}$ & Pneumonia, liver cirrhosis \\
\hline 79GSA125Ob18 & Unknown $^{\mathrm{b}}$ & 11 Dec 1979 & 11 Dec 1979 & Died at birth & Unknown \\
\hline Six individuals & Unknown & 1984 & Unknown & Unknown & Unknown \\
\hline
\end{tabular}

1Disclosed on multiple Internet websites (e.g. www.travelblog.org/Asia/Vietnam/blog-624450.html, http://bachhoa24.com/ dua-ca-heo-ong-su-vao-phuc-vu-du-lich-n-6156.html) 
decades of experience among cetacean researchers, veterinarians as well as zoological and other institutions, and have been applied primarily to common bottlenose dolphins. Carefully designed captures, conducted under suitable environmental conditions with ample experienced personnel and equipment, can be successful. R. S. Wells and colleagues have been conducting a comprehensive research study on a population of common bottlenose dolphins in Sarasota, Florida, since 1970. Their highly successful dolphin health assessment program has been ongoing for $>2$ decades and involves capture and an approximately $1 \mathrm{~h}$ health examination (including standardized measurements, ultrasound, temperature probe, and a suite of collected samples). Capture occurs in shallow, sheltered bay waters that are typically 1 to $4 \mathrm{~m}$ deep, providing relatively easy access, but may be up to $10 \mathrm{~m}$ deep. Capture operations are intensive, meticulous, highly coordinated, and rely on extremely experienced personnel, including vessel operators, researchers experienced in capture-release fishery operations and dolphin handling, as well as expert veterinary personnel (Scott et al. 1990, Wells et al. 2004, 2005, B. E. Curry pers. obs.). These animals are not transported, but are transferred from the capture net to foam pads and examined under shaded cover on a vessel (Wells et al. 2004). Total capture time ranges from 1 to $4 \mathrm{~h}$. More than 180 individuals have been successfully captured and released (Wells et al. 2004). In addition, the United States Navy Marine Mammal Program routinely transports captive bottlenose dolphins for military purposes (e.g. Olds 2003). Transport procedures and equipment have evolved since 1959 when the navy first began working with marine mammals, and today dolphins are safely transported (Reddy 1991, Houser et al. 2010), sometimes up to a day, by vehicle, vessel, and aircraft (DON 2009). Such transports can be extremely costly, relying on advanced military aircraft, for example, and are labor intensive, requiring experienced veterinary personnel and cetacean handlers.

\section{ACCLIMATION TO CAPTIVITY}

The acclimation period subsequent to transport is critical, as the individual may be recovering from capture stress and must adjust to many factors, including new surroundings, water conditions, interactions with conspecifics, as well as feeding and other human interactions. An understanding of the time needed for newly introduced individuals of a species to acclimate to captivity allows for improved marine mammal husbandry practices. The estimated acclimation period (during which the likelihood of mortality is higher than afterwards) for a common bottlenose dolphin Tursiops truncatus brought to captivity from the wild is $35 \mathrm{~d}$ (Small \& DeMaster 1995a). However, Small \& DeMaster (1995a) evaluated acclimation periods for wild-born $(\mathrm{n}=1270)$, captive-born $(\mathrm{n}=332)$, and captive-transferred $(\mathrm{n}=$ 911) bottlenose dolphins, along with those for wildborn $(\mathrm{n}=1650)$, captive-born $(\mathrm{n}=992)$, and captivetransferred ( $\mathrm{n}=336$ ) California sea lions Zalophus californianus and estimated a $60 \mathrm{~d}$ period of relatively high mortality for newly caught or captivetransferred marine mammals.

River dolphins have experienced high rates of mortality during acclimation post-capture and transport. There were 147 Amazon river dolphins Inia geoffrensis taken into captivity from 1956 to 2006 (Bonar et al. 2007). Analysis of pathology records for 123 of the 147 captive individuals indicated that mortality was highest in the first 2 mo post-capture and transport (32 of the 123 deaths; Bonar et al. 2007). A high incidence of pneumonia, which was identified as a cause of mortality within the first month of capture, was attributed to stress of capture and transport (Caldwell et al. 1989, Bonar et al. 2007). In about $25 \%$ of these cases, a predisposition to infection due to parasite load (pulmonary trematodes) may have existed. Amazon river dolphins also experienced a high incidence of bacterial disease (septicemia, without obvious symptoms) that led to sudden death in captivity (Bonar et al. 2007).

Mortality post-capture and transport was also high for the baiji Lipotes vexillifer (Chen \& Liu 1989). Of 6 baiji captured between 1981 and 1986, 3 died between $17 \mathrm{~d}$ and $4 \mathrm{mo}$ of capture, and a fourth died within 9 mo (Table 3; Chen \& Liu 1989).

South American fransiscanas Pontoporia blainvillei have only been held captive a few times, under poor conditions, in Uruguay. Two individuals survived only days in captivity during the 1950s (Monzón \& Corcuera 1991, Reeves \& Mead 1999), and 1 lived for several days held captive in the early 1970s (Brownell 1989).

Four female Indus river dolphins Platanista gangetica minor were captured and imported to the Steinhart Aquarium in San Francisco, California, from Pakistan in 1968 and 1970, but the 'rigors of capture and transport' were such that they survived for only 24, 38, and 44 d (McCosker 2007, Reeves \& Brownell 1989). Two died of pneumonia and the third had complications from a pre-existing injury to the lower jaw (Reeves \& Brownell 1989). At least 7 Indus river 
Table 3. Lipotes vexillifer. Survival times for baiji captured from the Yangtze River and introduced into captivity. After Braulik et al. (2005), and see Chen \& Liu (1989)

\begin{tabular}{|lcccccc|}
\hline Identification & Sex & Length $(\mathrm{cm})$ & Date captured & Date of death & Survival time & Institution \\
\hline Qi Qi & Male & 143 & 12 Jan 1980 & 14 Jul 2002 & 22 yr 190 d & Institute of Hydrobiology \\
Su Su & Female & 182 & 3 Mar 1981 & 20 Mar 1981 & 17 d & Nanjing Normal University \\
Rong Rong & Male & 151 & 22 Apr 1981 & 3 Feb 1982 & 228 d & Institute of Hydrobiology \\
Jiang Jiang & Male & 174 & 7 Dec 1981 & 16 Apr 1982 & 129 d & Nanjing Fisheries Research \\
& & & & & Institute \\
Lian Lian & Male & 203 & 31 Mar 1986 & 14 Jun 1986 & 76 d & Institute of Hydrobiology \\
Zhen Zhen & Female & 152 & 31 Mar 1986 & 1988 & 2 yr 182 d & Institute of Hydrobiology \\
\hline
\end{tabular}

dolphins were captured - 2 in December 1969 (Pilleri 1970), 1 in March 1972 (Pilleri 1972), and 4 in December 1972 (Pilleri et al. 1976) — for transport to the Brain Anatomy Institute in Berne, Switzerland (Reeves \& Brownell 1989).

Acclimation of narrow-ridged finless porpoises Neophocaena asiaeorientalis is not well documented. In one account from 2004, 9 finless porpoises (5 male, 4 female) were live-captured in Ise Bay, Japan, using 6 purse seine vessels (Miyashita et al. 2005). One male died $2 \mathrm{wk}$ after capture due to bacterial infection (methicillin-resistant Staphylococcus aureus [MRSA] strain of micrococcus; Miyashita et al. 2005, Morris et al. 2011).

One newborn vaquita Phocoena sinus stranded near Puerto Peñasco, Sonora, Mexico, on 13 May 1994, and was held captive at the Intercultural Center for the Study of Deserts and Oceans (CEDO), but only survived for a few hours (P. Turk Boyer pers. comm., 24 February 2012). No other specimens have been held in captivity.

Sixteen of the 20 Irrawaddy river dolphins Orcaella brevirostris captured from the Mahakam in 1974 and 1978 were held for approximately 1 mo periods in a net holding pen erected in the Pela tributary. The dolphins were transitioned from feeding on live to dead fish during these periods. Three of 6 dolphins died during this period in 1974, and 1 died at $30 \mathrm{~d}$ in 1978 (Ta'san et al. 1980; Table 2). Water in the holding pen was 'dirty and polluted,' and surviving individuals were administered antibiotics prior to transport (Ta'san et al. 1980).

An analysis of odontocete cetaceans that stranded alive in California waters from 1977 to 2002 illuminated the difficulties of stranded cetaceans in acclimating to captivity post-handling and transport (Zagzebski et al. 2006). The authors suggested that stress or pathologies related to the physical act of stranding and subsequent capture/transport procedures likely impeded successful rehabilitation of livestranded cetaceans.
Systematic investigation of the causes of mortality during acclimation could provide insight to the health concerns encountered during capture and acclimation of small cetacean species (Walker 1975). Bacterial infections, for example, are likely to relate, at least in part, to capture and transport, and may be more of a problem for freshwater species than for marine species. Improvements to sling design, climate control, and sanitary water quality, in addition to prophylactic anthelminthic treatment combined with broad-spectrum antimicrobial therapy, have been suggested to address some of the problems that have been encountered in the transport of Amazon river dolphins (Bonar et al. 2007) and would likely benefit other species, especially freshwater species. During a wide window of time (minimum $60 \mathrm{~d}$ ) surrounding the acclimation period, there is a need for close monitoring (e.g. of behavior, nutrition, water quality, and medical care; Joseph \& Antrim 2010), as well as minimization of potential stressors.

\section{MAINTAINING SMALL CETACEANS IN CAPTIVITY}

In general, zoos and aquariums have the most success maintaining and breeding species whose management needs are similar to those of domestic animals or other species with which zoos have had extensive experience. For example, zoos were able to maintain and breed California condors without much difficulty because they had years of experience with the closely related Andean condors Vultur gryphus (Ralls \& Ballou 1992). For species with which there is little prior experience, maintenance and breeding success may initially be poor until suitable husbandry techniques are developed (Ralls \& Meadows 2001, Kleiman et al. 2010, Ralls \& Ballou 2013).

Zoos and aquariums have had extensive, long-term experience and success with only a few small cetaceans other than bottlenose dolphins Tursiops 
spp. and killer whales Orcinus orca (e.g. Pacific whitesided dolphins Lagenorhynchus obliquidens, beluga whales Delphinapterus leucas, and Commerson's dolphins Cephalorhynchus commersonii; Asper et al. 1990). In addition, relatively few longitudinal data regarding mortality and survival of individual cetacean species in captivity are available for comparison among species and institutions (DeMaster \& Drevenak 1988, Duffield \& Wells 1991, Reeves et al. 1994). Today, with the International Species Information System (ISIS) and the advent of the Zoological Information Management System (ZIMS) as a repository for standardized collections data, better comparisons may become possible for a wider variety of species and institutions.

Even so, the infrastructure, funding level, and extent of cumulative experience at individual institutions are likely to have a strong influence on small cetacean survival rates. Comparison of available zoological records (dates of captures, births, deaths) has shown significant differences in survival rates of captive common bottlenose dolphin among institutions (DeMaster \& Drevenak 1988). For killer whales, mortality has been found to be highest from captive birth to $1 \mathrm{yr}$ of age, and for individuals in their first year of captivity (DeMaster \& Drevenak 1988, see also Bigg \& Wolman 1975, Greenwood \& Taylor 1985). Male killer whales had lower survival rates in captivity than females, but sex-specific survival rates were similar for both bottlenose dolphins and beluga whales (DeMaster \& Drevenak 1988). Survival of captive bottlenose dolphin and killer whale calves was significantly lower than in wild populations (Small \& DeMaster 1995b). Innes et al. (2005) compared institutional records from 1973 to 2003, and documented a slight but significant increase in annual survival rates for bottlenose dolphins over time. Increased survival rate was attributed to improvements in husbandry and veterinary care, as well as institutional efforts to improve care for this species.

River dolphins have proved difficult to maintain. Amazon river dolphins Inia geoffrensis, baiji Lipotes vexillifer, and South Asian river dolphins Platanista gangetica have all had poor survival rates in captivity (Caldwell et al. 1989, Chen \& Liu 1989, Reeves \& Brownell 1989). However, survival rates have not been calculated controlling for level of experience in capturing different species; for instance, comparing survival rates for the first 20 Amazon River dolphins brought into captivity with those for the first 20 bottlenose dolphins brought into captivity. Such a standardized analysis would enable researchers to distin- guish between the possibility that poor survival rates in Amazon river dolphins are due to inexperience in capturing and husbandry of this species, and the possibility that this species is more difficult to capture and maintain successfully than bottlenose dolphins due to some biological differences between the species. This specific analysis cannot be conducted because there are no data on the survival of the first 20 bottlenose dolphins taken into captivity.

Examination of post-mortem records for captive Amazon river dolphins (97 of 147) indicated that, as in bottlenose dolphins (DeMaster \& Drevenak 1988), mortality was highest in the first year of captivity (Bonar et al. 2007). Only 9 of 97 river dolphins remained alive after $10 \mathrm{yr}$ in captivity. Longevity in captivity is 10 to 26 yr (Best \& da Silva 1993). Control of microbiological water quality is considered vital to maintenance, and a robust preventative medical program aimed at preventing bacterial infection may promote the longevity of Amazon river dolphins in captivity (Caldwell et al. 1989, Bonar et al. 2007).

The longest surviving baiji, the only 1 of 6 captives to live $>3 \mathrm{yr}$, was rehabilitated from injuries and lived 22 yr (Chen \& Liu 1989, Braulik et al. 2005). The next longest surviving captive baiji lived for $2 \mathrm{yr} 182 \mathrm{~d}$ (Chen \& Liu 1989, Braulik et al. 2005; Table 3). One additional individual was held in semi-natural conditions from December 1996 to June 1997, surviving $187 \mathrm{~d}$ in the Shishou Reserve, Hubei Province, China (Liu et al. 2002).

Some of the 7 Indus river dolphins Platinista gangetica minor known to have been captured and transported to the Brain Anatomy Institute are thought to have survived for several years (Reeves \& Brownell 1989). One Indus river dolphin female was maintained at the Steinhart Aquarium from May 1970 to July 1971 (Reeves \& Brownell 1989). In 1970, 5 (1 male, 4 female) Ganges river dolphins P. $g$. gangetica survived in captivity at Kamogawa Sea World from 64 to 299 d (Reeves \& Brownell 1989, Tobayama \& Kamiya 1989, Reeves \& Mead 1999). Indus river dolphins have survived for up to $5 \mathrm{yr}$ in captivity (Reeves \& Mead 1999, Collet 1984).

Most individuals captured during early attempts to maintain the Yangtze finless porpoise Neophocaena asiaeorientalis asiaeorientalis in China died in $<1 \mathrm{yr}$ (Liu et al. 2002, Wang 2009). There are currently 3 main holding areas for these porpoises in China (Wang 2009). One is the semi-natural Shishou Reserve (in the Tian'e-Zhou Oxbow of the Yangtze River), where animals are able to interact freely and into which 49 Yangtze finless porpoises have been introduced since 1990 (Wang et al. 2000, Wang 2009). 
Approximately 30 porpoises occupied the reserve in 2010. Another small reserve, currently occupied by 10 porpoises, was established in Tongling, Anhui Province, in 1994 (Wang et al. 2010). Females produce calves annually in these reserves (Wang 2009, Wang et al. 2010). The third main holding area is an aquarium at the Institute of Hydrobiology (IHB) in Wuhan, which was maintaining 5 Yangtze finless porpoises in 2009, including 1 captive-born male (Table 4; Wang 2009). The IHB maintained 6 porpoises (3 male, 3 female) in 2010 (Wang et al. 2010, Zhang et al. 2012).

Both subspecies of narrow-ridged finless porpoise Neophocaena asiaeorientalis - the Yangtze finless porpoise N. a. asiaeorientalis and the East Asian finless porpoise $N$. a. sunameri-from coastal marine waters are currently housed at institutions in China (Zhang et al. 2012). Six of these are the Yangtze finless porpoises at the IHB (Wang et al. 2010); the remaining 9 (3 males, 6 females) are individuals of both subspecies at other institutions (see Zhang et al. 2012).

Irrawaddy dolphins Orcaella brevirostris have been maintained in captivity in Indonesia, Thailand, Japan, and Cambodia. Although mortality rates during capture and acclimation have been high for individuals of the Mahakam River subpopulation, captive survival rates once on public display in Indonesia are not well known (Tas'an et al. 1980, Tas'an \& Leatherwood 1984, Stacey \& Leatherwood 1997,
Wirawan 1989). There has been no known live capture for display purposes from other freshwater Irrawaddy dolphin populations, but coastal Irrawaddy dolphins have been captured in Thai and Cambodian waters (Perrin et al. 1996, 2005, Stacey 1996, Beasley 2007, Beasley \& Davidson 2007). The total numbers removed are unknown (Reeves \& Fisher 2005). Irrawaddy dolphins have been housed in 2 facilities in Thailand (Oasis Sea World, Chantaburi Province, and Safari World, Bangkok aquariums; Stacey 1996, Stacey \& Leatherwood 1997, Beasley 2007). Ten wild-caught Irrawaddy dolphins (4 males and 5 females taken in 1983, and 1 male taken in 1988) were reported to be housed at Oasis Sea World in 2002 (Beasley 2002).

In 1994, 8 Irrawaddy dolphins were caught using nets in the coastal waters of Cambodia and taken into captivity at Safari World, Bangkok (Stacey \& Leatherwood 1997). In 1995, 2 Irrawaddy dolphins, thought to have been from the 1994 collection, were exported by Safari World to Marine World Uminonakamichi, Fukuoka City, Japan, but both have since died (T. K. Yamada pers. comm., 16 September 2009; Stacey 1996, Stacey \& Leatherwood 1997). We could not find information regarding the length of captive survivorship for these individuals. Beasley (in Perrin et al. 2005) reported that at least 8 Irrawaddy dolphins were captured in Cambodian coastal waters in January 2002 and then transferred to the Koh Kong International Resort Hotel on the Thailand/Cambodia

Table 4. Neophocaena asiaeorientalis asiaeorientalis. Yangtze finless porpoise taken into captivity in China. After Liu et al. (2002) and Braulik et al. (2005). -: single individual, sex unknown

\begin{tabular}{|c|c|c|c|c|}
\hline Individual & Year captured & Survival time & Institution & Source \\
\hline- & 1965 & $245 \mathrm{~d}$ & Quingdao Marine Museum & $\begin{array}{l}\text { Liu et al. (2002), Braulik et al. (2005), } \\
\text { Wang (2009) }\end{array}$ \\
\hline Multiple & During 1970-1980 & $\sim 1 \mathrm{yr}$ & Shanghai Zoo & Liu et al. (2002), Braulik et al. (2005) \\
\hline- & 1978 & $60 \mathrm{~d}$ & Institute of Hydrobiology & Liu et al. (2002), Braulik et al. (2005) \\
\hline- & 1981 & $\sim 1 \mathrm{yr}$ & Institute of Hydrobiology & Liu et al. (2002), Braulik et al. (2005) \\
\hline- & 1985 & $180 \mathrm{~d}$ & Institute of Hydrobiology & Liu et al. (2002), Braulik et al. (2005) \\
\hline- & 1988 & 2 yr $29 \mathrm{~d}$ & Nanjing Normal University & Liu et al. (2002), Braulik et al. (2005) \\
\hline Multiple & 1992 & Longest 1 yr 3 mo & Tongling Conservation Farm & Liu et al. (2002), Wang (2009) \\
\hline- & 1992 & $180 \mathrm{~d}$ & China Aquarium of Shanghai & Liu et al. (2002), Braulik et al. (2005) \\
\hline- & 1993 & 1 yr 6 mo & Institute of Hydrobiology & Liu et al. (2002), Braulik et al. (2005) \\
\hline 1 male & 1996 & Alive in 2009 & Institute of Hydrobiology & $\begin{array}{l}\text { Liu et al. (2002), Braulik et al. (2005), } \\
\text { Wang (2009) }\end{array}$ \\
\hline 1 female & 1996 & Alive in 2009 & Institute of Hydrobiology & $\begin{array}{l}\text { Liu et al. (2002), Braulik et al. (2005), } \\
\text { Wang (2009) }\end{array}$ \\
\hline- & 1997 & $1 \mathrm{yr}$ & Wuhan New Century Aquarium & Liu et al. (2002), Braulik et al. (2005) \\
\hline Multiple & $1999-2001$ & $1 \mathrm{yr}$ & Wuhan New Century Aquarium & Liu et al. (2002), Braulik et al. (2005) \\
\hline 1 female & 1999 & $8 \mathrm{yr}$ & Institute of Hydrobiology & Liu et al. (2002), Wang (2009) \\
\hline 1 male & 1999 & Alive in 2009 & Institute of Hydrobiology & Liu et al. (2002), Wang (2009) \\
\hline 1 male $^{a}$ & 2004 & Alive in 2009 & Institute of Hydrobiology & Wang (2009) \\
\hline
\end{tabular}


border. They were thought to have died within $5 \mathrm{yr}$ (Beasley \& Davidson 2007). Significant problems with water quality and feeding have been reported for institutions in Indonesia and Thailand (Tas'an et al. 1980, Perrin et al. 1996, Stacey \& Arnold 1999).

In recent decades, many advances have been made in husbandry and maintenance of small cetaceans in the captive environment, including improvements in health care, nutrition, water quality, space requirements, and behavioral stimulation (Brando 2010, Joseph \& Antrim 2010). However, because husbandry techniques are often species specific, new captive breeding programs may require substantial research development for captive care with regards to behavior, reproductive physiology, nutrition, and disease (Ralls \& Meadows 2001, Kleiman et al. 2010, Ralls \& Ballou 2013).

\section{BREEDING SMALL CETACEANS IN CAPTIVITY}

Many wild-caught animals fail to breed in captivity (Lees \& Wilcken 2009). As noted above, this failure is often due to behavioral problems caused by inade- quate husbandry techniques (Ralls \& Meadows 2001, Ralls \& Ballou 2013). Success with captive breeding of dolphins that live in rivers has been extremely limited (Table 5; Reeves \& Mead 1999). Amazon river dolphins Inia geoffrensis were widely held in captivity from the early 1950 s to the late 1970 s, but Caldwell et al. (1989) reported only 2 live captive births. Both calves died shortly after birth: 1 after minutes and 1 after approximately 2 wk (Huffman 1970, Caldwell \& Caldwell 1972). However, from 2000 to 2009, live births of 3 calves conceived in captivity occurred at the Valencia Aquarium (Boede 2005, Bonar et al. 2007, Pelaez 2010, Rojas 2010). Two of these have died (see Table 5).

In 2011, 4 of the 6 Amazon river dolphins maintained at the Valencia Aquarium (including a captive-conceived female born in 2009) died in a 4 mo period of causes generally attributed to poor conditions, e.g. poor water quality and ingestion of foreign objects including debris from the deterioration of railings that surrounded enclosures (Table 6; AN Venezuela 2011a,b).

There has been success breeding captive narrowridged finless porpoises Neophocaena asiaeorien-

Table 5. Reported live captive births for Amazon river dolphins Inia geoffrensis, Yangtze finless porpoise Neophocoena asiaeorientalis asiaeorientalis, and Irrawaddy dolphins Orcaella brevirostris (Mahakam River subpopulation) held in captivity between 1956 and 2011. -: no information available

\begin{tabular}{|c|c|c|c|c|c|c|c|}
\hline Species & Institution & Identification & Sex & $\begin{array}{l}\text { Date of } \\
\text { birth }\end{array}$ & $\begin{array}{c}\text { Date of } \\
\text { death }\end{array}$ & $\begin{array}{l}\text { Survival } \\
\text { time }\end{array}$ & Source \\
\hline \multirow[t]{5}{*}{ I. geoffrensis } & $\begin{array}{l}\text { Fort Worth } \\
\text { Zoological Park }\end{array}$ & - & - & 1970 & 1970 & $\begin{array}{l}\text { Died at } \\
\text { birth }\end{array}$ & $\begin{array}{l}\text { Huffman (1970), } \\
\text { Caldwell et al. (1989) }\end{array}$ \\
\hline & $\begin{array}{l}\text { Marineland of } \\
\text { Florida }\end{array}$ & - & - & - & - & $15 \mathrm{~d}$ & $\begin{array}{l}\text { Caldwell \& Caldwell (1972), } \\
\text { Caldwell et al. (1989) }\end{array}$ \\
\hline & $\begin{array}{l}\text { Valencia } \\
\text { Aquarium }\end{array}$ & Telemachus & Female & Nov 2000 & 2005 & $\sim 5 \mathrm{yr}$ & Pelaez (2010), Rojas (2010) \\
\hline & $\begin{array}{l}\text { Valencia } \\
\text { Aquarium }\end{array}$ & Zeus & Male & Nov 2005 & Alive in 2011 & - & Boede (2005) \\
\hline & $\begin{array}{l}\text { Valencia } \\
\text { Aquarium }\end{array}$ & Helena II & Female & $\begin{array}{l}23 \text { Oct } \\
2009\end{array}$ & 14 Apr 2011 & $1 \mathrm{yr} 173 \mathrm{~d}$ & Pelaez (2010), Rojas (2011) \\
\hline \multirow[t]{3}{*}{$\begin{array}{l}\text { N. p. } \\
\text { asiaeorientalis }\end{array}$} & $\begin{array}{l}\text { Institute of } \\
\text { Hydrobiology }\end{array}$ & - & Male & 2005 & Alive in 2011 & - & $\begin{array}{l}\text { Wang et al. (2005), } \\
\text { Wang (2009) }\end{array}$ \\
\hline & $\begin{array}{l}\text { Institute of } \\
\text { Hydrobiology }\end{array}$ & - & Male & 2007 & 2007 & $39 \mathrm{~d}$ & Wang (2009) \\
\hline & $\begin{array}{l}\text { Institute of } \\
\text { Hydrobiology }\end{array}$ & - & Male & 2008 & 2008 & $5 \mathrm{~d}$ & Wang (2009) \\
\hline \multirow[t]{2}{*}{ O. brevirostris } & $\begin{array}{l}\text { Jaya Ancol } \\
\text { Oceanarium }\end{array}$ & $\begin{array}{c}\text { Isui } \\
\text { (79GSA105mOb17) }\end{array}$ & Female & $\begin{array}{l}4 \text { Jul } \\
1979\end{array}$ & Deceased & $\begin{array}{l}\text { Unknown; } \\
\text { alive in } 1984\end{array}$ & $\begin{array}{l}\text { Tas'an et al. (1980), } \\
\text { Tas'an \& Leatherwood } \\
\text { (1984), Beasley (2007) }\end{array}$ \\
\hline & $\begin{array}{l}\text { Jaya Ancol } \\
\text { Oceanarium }\end{array}$ & - & - & - & Deceased & $\begin{array}{l}\text { Unknown; } \\
\text { alive in } 1984\end{array}$ & $\begin{array}{l}\text { Tas'an et al. (1980), } \\
\text { Tas'an \& Leatherwood } \\
\text { (1984), Beasley (2007) }\end{array}$ \\
\hline
\end{tabular}


Table 6. Inia geoffrensis. Amazon river dolphins captured from 1975 to 1994 in the Orinoco River (Apure River tributary, Guariquito River), Venezuela, and taken into captivity at the Valencia Aquarium (Venezuela) as reported by Boede et al. (1998). Survival times are reported if known. -: no information available

\begin{tabular}{|c|c|c|c|c|c|c|}
\hline Location & Sex & Individual & $\begin{array}{c}\text { Date } \\
\text { captured }\end{array}$ & $\begin{array}{c}\text { Date of } \\
\text { death }\end{array}$ & $\begin{array}{l}\text { Survival } \\
\text { time }\end{array}$ & Reported pathologies \\
\hline \multirow[t]{3}{*}{ Apure River } & $\begin{array}{c}5 \text { male, } \\
3 \text { female }\end{array}$ & & 1975 & Deceased & Not known & - \\
\hline & 1 male & Arquimides & 1975 & Jun 1987 & $\sim 12 \mathrm{yr}$ & Gastrointestinal obstruction, gastric ulcers \\
\hline & 1 female & Nelly & 1975 & $\begin{array}{l}6 \mathrm{Nov} \\
1993\end{array}$ & $\sim 18 \mathrm{yr}$ & Warfarin poisoning (rodenticide) \\
\hline \multirow[t]{6}{*}{$\begin{array}{l}\text { Guariquito } \\
\text { River }\end{array}$} & 1 female & & $\begin{array}{c}10 \mathrm{Jul} \\
1987\end{array}$ & - & $\begin{array}{c}\text { Released } \\
\text { after capture }\end{array}$ & - \\
\hline & 1 male & Ulyses & $\begin{array}{l}10 \mathrm{Jul} \\
1987\end{array}$ & $\begin{array}{l}13 \mathrm{Jan} \\
2011^{\mathrm{b}}\end{array}$ & 23 yr 194 d & Bronchopneumonia, hepatitis ${ }^{\mathrm{c}}$ \\
\hline & 1 female & Dalila & $\begin{array}{c}10 \mathrm{Jul} \\
1987\end{array}$ & & $\begin{array}{c}\text { Alive in } 2011 \\
\quad(23 \mathrm{yr})\end{array}$ & \\
\hline & 1 female & Penelope & $\begin{array}{c}20 \mathrm{Apr} \\
1994\end{array}$ & $\begin{array}{c}25 \mathrm{Mar} \\
2011^{\mathrm{b}}\end{array}$ & 16 yr $344 \mathrm{~d}$ & $\begin{array}{l}\text { Acute ulcerative gastritis, ingestion of } \\
\text { foreign material (note subsequent death of } \\
\text { offspring 'Helena II' from same cause; } \\
\text { see Table } 5)^{\mathrm{c}}\end{array}$ \\
\hline & 1 female & Helena I & $\begin{array}{c}20 \mathrm{Apr} \\
1994\end{array}$ & Deceased & Not known & - \\
\hline & 1 female $^{a}$ & Artemis & $\begin{array}{l}19 \text { Oct } \\
1994\end{array}$ & $\begin{array}{l}5 \mathrm{Feb} \\
2011^{\mathrm{b}}\end{array}$ & 16 yr $114 d$ & Hepatitis, pancreatitis, gastric ulcers ${ }^{\mathrm{c}}$ \\
\hline
\end{tabular}

talis in Japan since the mid-1970s (Furuta et al. 1976, Wang et al. 2000, Miyashita et al. 2005). Captive breeding of Yangtze finless porpoises N. a. asiaeorientalis in China has taken decades to organize and has included considerable trial and error (Perrin et al. 1989, Wang et al. 2000, 2006, Wang 2009). Currently, captive breeding is considered to be an integrated part of an overall conservation effort for this subspecies in China, including the establishment of reserve areas for wild populations (Wang 2009). In recent years, improved science and husbandry, international collaboration and specialized staff training have contributed to some success in captive breeding. In 2005, after 9 yr in captivity, 1 female produced the first captive-born individual of this subspecies (Wang et al. 2005), and the male offspring was reported to remain healthy (Wang et al. 2010). ${ }^{\underline{2}}$ The same female gave birth to a second calf in June 2007 and died 39 d later, followed by the death of the calf after $11 \mathrm{~d}$. In July 2008, the second female gave birth to a calf, but did not lactate, and the calf died after 5 d (Wang 2009; Table 5).

As a part of captive breeding in China, reproductive husbandry protocols were developed and applied to captive Yangtze finless porpoises, and research evaluating reproductive physiology of the subspecies preceded the 2005 birth (Liu et al. 2002, Wang 2009). Blood samples of captive porpoises were collected monthly (as part of an overall evaluation of physical condition), with fecal, saliva, and blowhole secretion samples collected daily in an attempt to monitor reproductive hormones (Wang 2009). Behavioral observations were undertaken to monitor mating activities (Wei et al. 2004). In addition, Chen et al. (2006) monitored levels of serum testosterone in 1 of the 2 captive males over an approximately 6 yr period from 1997 to 2003 (and see Wu et al. 2010), and opportunistic endocrine monitoring of 66 (41 male, 25 female) free-ranging finless porpoises provided preliminary information on serum gonadotropins and steroid hormones (Hao et al. 2007).

A few live births of Irrawaddy dolphins Orcaella brevirostris, conceived in captivity, have occurred in 2 aquariums: 2 healthy dolphins were born at the Jaya Ancol Oceanarium (Tas'an et al. 1980, Tas'an \&

\footnotetext{
2This captive born male and a rehabilitated individual captured after sustaining injuries in 2008, were released into the Tian'e-Zhou Oxbow in April 2011 (http://wwfen.panda. org/?3440/)
} 
Leatherwood 1984, Stacey 1996; Tables 2 \& 6), and an unknown number of births has occurred at Oasis Sea World, Chantaburi Province (Perrin et al. 1996, Stacey 1996, Stacey \& Arnold 1999); 3 captive-born Irrawaddy dolphins (ages approximately 8 to $10 \mathrm{yr}$ ) were reported to be housed at that facility in 2002 (Beasley 2002).

Among many other factors potentially affecting breeding success of small cetaceans, social grouping is often critical (e.g. avoiding possible suppression of spermatogenesis in subordinate male bottlenose dolphins; O'Brien \& Robeck 2010a). Inappropriate social grouping can also have detrimental effects on health and longevity of small cetaceans in captivity. Unsuccessful breeding and short lifespan of Amazon river dolphins in captivity has been attributed, in part, to a lack of knowledge regarding aggressive behavior in social groupings (for example, larger males need to be separated from other animals) and to stressrelated diseases associated with transport and housing (Sylvestre 1985, Caldwell et al. 1989, Best \& da Silva 1993). A comparison of pool size and number of individuals that had been housed among 13 institutions indicated a statistically significant correlation, likely to be related to water quality and space requirements among individuals, between dolphin survival and volume of water available (Bonar et al. 2007).

\section{ASSISTED REPRODUCTIVE TECHNOLOGIES}

Assisted reproductive technologies (ART) can be useful to enhance captive breeding programs for the conservation of endangered species. The benefits of using artificial insemination (AI) and associated procedures such as the synchronization of estrus include improved genetic management of propagation (facilitating use of 1 sire to several females by extending semen; allowing more efficient breeding amongst institutions without animal transport) and a potentially shorter interval between generations (Andrabi \& Maxwell 2007, Thomassen \& Farstad 2009). O'Brien \& Robeck (2010a) reviewed the development and use of these technologies, including AI, estrus synchronization, sperm preservation, and sperm sexing in cetaceans. These techniques can be useful for efficient genetic management of captive cetacean populations. However, the preservation of a species requires routine and efficient production of progeny, and, although there have been successes applying ART in large-scale captive breeding with a few species, such as the peregrine falcon Falco peregrinus
(Cade 1988), many applications of ART have been limited or 1-time events. Many failed attempts at assisted reproduction go unreported (Wildt et al. 1993).

Assisted reproductive technologies are species specific, and some aspects of these technologies are inefficient for many endangered species because of insufficient knowledge of basic reproduction such as structural anatomy, estrous cycle, seasonality, gamete physiology, and site for semen deposition (Wildt et al. 1986, Wildt 1989, Comizzoli et al. 2000, Andrabi \& Maxwell 2007). In addition, there are at least 2 initial criteria that must be met for AI and associated reproductive technologies to benefit endangered species. First, the captive population should be breeding successfully. Artificial insemination is best achieved when applied to populations that are currently reproducing successfully, not as a substitute for reproductive viability, but as a tool for improving the efficiency of breeding management (Lasley \& Anderson 1991, Robeck et al. 1994). Second, to successfully use AI and other ART, it is essential to have a fundamental understanding of reproductive anatomy and detailed knowledge of reproductive physiology for both males and females of the species concerned (Wildt et al. 1986, Wildt 1989, Robeck et al. 1994, 2004, 2005b).

There have been successes in the AI of 5 cetacean species, but these have occurred at only a few institutions after decades of species-specific research combined with highly refined clinical experience. Results of the first successful AI trials included the live births of 3 common bottlenose dolphins Tursiops truncatus (Robeck et al. 2005b), 2 killer whales Orcinus orca (Robeck et al. 2004), 1 beluga whale Delphinapterus leucas (O'Brien et al. 2008), and 5 Pacific white-sided dolphins Lagenorhynchus obliquidens (Robeck et al. 2009). O'Brien \& Robeck (2010a) recounted collaboration amongst 36 researchers and institutions and that an additional 18 bottlenose dolphins, 2 killer whales, 3 belugas, and 1 Indo-Pacific bottlenose dolphin were produced from AI (6 of these were reported as still in utero from AI procedures conducted during 2010). This work marks a significant achievement for cetacean science and collections management and, if $\mathrm{AI}$ is proven replicable for these species (as it has been for common bottlenose dolphins), will allow for careful planning and selection of breeding combinations without requiring transportation of individuals amongst facilities. In addition, the research may contribute to the goal of sharing the gene pool amongst zoological institutions worldwide, thereby potentially enhancing captive 
populations (Ballou et al. 2010) and diminishing the impetus to collect individuals from the wild (Robeck et al. 1994).

The research that was conducted to achieve the successful AI procedures noted above has contributed greatly to the scientific knowledge of reproduction in these species, providing the potential for future use in applied wildlife conservation in situ and efforts ex situ (Wildt et al. 1992, O'Brien \& Robeck 2010a). However, although the application of ART for a variety of mammalian species is becoming increasingly successful, it is often the case that the most significant contribution of the research required to develop ART is better scientific knowledge (e.g. Howard \& Wildt 2009) and improved captive management of the species involved. Because of the intensive level of investigation required to develop species-specific reproductive techniques and the logistical constraints of their application, the outcome of research efforts is often a deeper understanding of the unique adaptive traits and physiological mechanisms that define a particular species, rather than large-scale assisted breeding or even the production of numerous offspring (Wildt et al. 1992, Wildt \& Wemmer 1999, Goodrowe et al. 2000, Andrabi \& Maxwell 2007).

Some of the problems encountered during trials of $\mathrm{AI}$ in captive cetaceans have occurred at the methodological development stage (Robeck et al. 2004). Robeck et al. (2005b) noted that their success with common bottlenose dolphins highlights the value of strategic, systematic research into the basic reproductive physiology of a species for the development of ART. Because the common bottlenose dolphin has been most widely maintained in captivity, research on reproduction in this species has been particularly thorough (Schroeder 1990, Schroeder \& Keller 1990, Robeck et al.1994, 2005b). The earliest reports detailed reproductive behavior (e.g. Tavolga \& Essapian 1957) and anatomy (Harrison 1969, Harrison et al. 1972, Harrison \& McBreaty 1977, Bryden \& Harrison 1986). Also, scientific knowledge of bottlenose dolphin (and other cetacean species) reproductive biology has been greatly enhanced by opportunistic investigation of stranded, by-caught, and exploited specimens (e.g. Perrin \& Reilly 1984). In the late 1970s and 1980s, Cornell et al. $(1977,1987)$ reported results of research focused on 1 multi-facility breeding colony (beginning with work in the early 1960s) and established plans for future captive breeding and the potential use of ART (Robeck et al. 1994).

Research on bottlenose dolphins determined basic information regarding reproductive biology, includ- ing timing of ovulation and the estrous cycle, as well as aspects of the seasonality of reproduction in females (Sawyer-Steffan et al. 1983, Kirby \& Ridgway 1984, Yoshioka et al. 1986, Kirby 1990, Schroeder 1990, Urian et al. 1996) and variation in testosterone levels among age classes and seasons in males (Harrison \& Ridgway 1971, Yoshioka et al. 1986, Kirby 1990, Schroeder \& Keller 1989). In addition, long-term, systematic evaluation of endocrine changes (in particular rapid detection of changes in urinary luteinizing hormone) elucidating ovarian activity and collection of these data in conjunction with ultrasound evaluation of ovarian changes and male reproductive characteristics (Brook 2001, Robeck et al. 2005b, Robeck and Monfort 2006) were necessary to achieve success with AI in bottlenose dolphins. Likewise, intricate details of reproductive endocrine physiology in female and male killer whales, beluga whales, Pacific white-sided dolphins, and Indo-Pacific bottlenose dolphins were needed to achieve the first successful AI in these species (Walker et al. 1988, Robeck et al. 1993, 2004, 2005a, 2009, O'Brien et al. 2008, O'Brien \& Robeck 2010a).

Detailed knowledge of sperm characteristics and production (Fleming et al. 1981, Miller et al. 2002, Robeck \& Monfort 2006, Yuen 2007, O'Brien et al. 2008), as well as semen preservation (Robeck \& O'Brien 2004, O'Brien et al. 2008, Robeck et al. 2009, O'Brien \& Robeck 2010a), have been fundamental to the success of AI for each of these species. Semen collection methodology is particularly important and must be entirely voluntary on the part of the donor (which can be achieved through a series of training procedures) to yield an acceptable level of sperm quality (Robeck \& Monfort 2006, Yuen et al. 2009). Semen preservation is imperative; currently multiple cryopreservation methods are being tested and developed for use in some cetacean species (O'Brien \& Robeck 2010b). Recent advances in reproductive technology and research regarding bottlenose dolphin sperm characteristics have allowed for refinement of sperm sexing and pre-selection of sex in this species (O'Brien \& Robeck 2006, 2010a, O'Brien et al. 2009).

Species-specific research will be required to develop reproductive knowledge for the application of ART to captive propagation for any new small cetacean. Development of gamete preservation for biological resource banking and organized banking of spermatozoa may be of future value for conservation of small cetacean species (Wildt et al. 1997, O'Brien \& Robeck 2010a). 


\section{LOGISTICAL REQUIREMENTS FOR CAPTIVE BREEDING}

Many practical objectives must be met before a captive breeding population can be established for a new species of small cetacean and ART can be used safely and successfully. Captive breeding programs as a means of species conservation should not be instituted ad hoc, but should be systematically developed to integrate potential solutions to multiple risk factors. Recently revised IUCN guidelines on the management of ex situ populations for conservation include a broad outline for the assessment of feasibility and risk (both risk factors in the wild and risk imposed on the target taxon by the process of ex situ conservation) as a part of the overall decision-making process for implementing ex situ conservation efforts (IUCN 2012). Guidelines include stepwise risk assessment criteria that may prove useful for determining if and when individuals should be removed from the wild and for prioritization of captive breeding efforts. Decisions must be made regarding the number of individuals that can be removed from the wild population and the risk criteria that must be assessed on a per species basis prior to initiating a captive breeding program. Once fully established, these guidelines may prove useful to developing strategies for the conservation of small cetacean species.

Additional requirements must be met to supply the proper housing, nutrition, behavioral stimulation, and preventive medicine required for the care of small cetaceans. While governmental and institutional organizations sometimes develop guidelines for marine mammals in the captive environment, special considerations are necessary to the maintenance of these animals, and, realistically, zoological institutions must often exceed minimum requirements to achieve success (Joseph \& Antrim 2010). Currently, there are several international organizations that may provide a useful baseline of standards for regulating zoos and aquariums aspiring to maintain cetaceans for captive breeding purposes. For example, the World Association of Zoos and Aquariums (WAZA) and Association of Zoos and Aquariums (AZA) have established codes of ethics, and the AZA has established an accreditation commission intended to uphold rigorous standards of animal management and care, as well as an extensive collection or 'acquisition-disposition policy,' and guidelines for 'developing an institutional program animal policy. ${ }^{\prime} \mathbf{3}$

A captive breeding program should be undertaken only when in situ conservation is proving uncertain and when there is a long-term commitment of the substantial financial resources required, including buy-in from local and national government agencies. In addition, a captive breeding program should be developed as an integrated component of an overall conservation effort for a threatened taxon, including the goals of public awareness, population management reinforcement or reintroduction, and other support to wild populations (including habitat protection, restoration, and management), long-term banking of biological samples, scientific research, and fundraising (IUCN 2012). High cost is inherent to such recovery programs. For example, total United States Fish and Wildlife Service (USFWS) California Condor Recovery Program costs have exceeded 35 million US dollars, and cost estimates for 2010 to 2014 for the USFWS Black Footed Ferret Species Action Plan total in excess of 30 million US dollars. $\underline{4}^{4}$

Captive populations require careful demographic and genetic management, with sufficient numbers of reproductively viable, sexually mature males and females available in the founder population, as well as an eventual captive population large enough to avoid excessive loss of genetic diversity and a high risk of extinction (e.g. Ralls 1989, Ralls \& Ballou 1992, Ralls $\&$ Meadows 2001, Ballou et al. 2010). Hence, a major difficulty for successful captive breeding of cetaceans is finding sufficient ex situ habitat of adequate quality in semi-natural reserves or in aquariums.

The overall infrastructure of a captive breeding program for small cetaceans must include experienced personnel (handlers, trainers, nutritionists, veterinarians, scientists) and facilities that meet or exceed international standards for housing sufficient numbers of individuals. Husbandry and veterinary facilities including those for nutritional and medical care, as well as specialized technological equipment for both routine and emergency healthcare, will also be necessary. Use of ART requires a fully equipped laboratory for work including endocrine monitoring, microscopy for semen and potentially other analyses, ultrasonographic and endoscopic equipment, along with standardized liquid nitrogen and freezer storage for cryopreservation (Robeck \& O'Brien 2004, Robeck et al. 2004, 2005a,b, 2009, Robeck \& Monfort 2006, O'Brien et al. 2008, Yuen et al. 2009, O'Brien \& Robeck 2010a).

\footnotetext{
${ }^{3}$ Information regarding WAZA code of ethics and AZA code of ethics, policies, institutional accreditation, and taxon advisory groups is accessible at www.waza.org/en/site/home and www.aza.org

${ }^{4}$ Information available at http://ecos.fws.gov/speciesProfile/
} 
Although the quality of husbandry and medical care for all captive species should meet, and indeed often exceed, the highest prescribed standards (e.g. Joseph \& Antrim 2010), this is not always the case. The best husbandry methods for small cetaceans are those that require the least amount of restraint and attain maximum cooperation from the animal (Ridgway et al. 1989). This approach is strongly evident in the research that has resulted in successful AI in small cetaceans and is, in fact, needed for collection of suitable-quality urine and semen samples (Robeck et al. 2004, 2005a,b, 2009, O'Brien et al. 2008). To carry out research and implement ART in cetaceans (and for the routine husbandry associated with captivity and captive breeding), captive individuals must be trained and conditioned to allow safe, voluntary (unrestrained) handling and husbandry procedures, including voluntary urine, blood, and semen donation, as well as vaginal manipulation (Keller 1986, Lenzi 2000, Surovik et al. 2001, Fripp et al. 2005, Robeck \& Monfort 2006, Yuen et al. 2009, O'Brien \& Robeck 2010a). Training animals for these procedures requires experienced trainers and may be best achieved with continuity between trainers and dolphins over extended periods of time. Implementation of these routine husbandry procedures will require the physical presence of qualified, experienced veterinary personnel, and the implementation of ART will require the presence of a veterinarian with expertise in that field and ongoing participation of other qualified, experienced veterinary personnel and scientists.

\section{CHALLENGES OF REINTRODUCING CAPTIVE-BRED ANIMALS}

Even if a species can be bred routinely in captivity, use of captive-bred individuals to reinforce wild populations or reintroductions of captive-bred animals to form a new population in suitable ecological habitat can be difficult, complex, and costly (Kleiman 1996, Seddon et al. 2007, Earnhardt 2010). While there have been successful species reintroductions, and there may be circumstances when reinforcement or reintroduction is the best advisable conservation measure, there have been many more failures (Jule et al. 2008, Bowkett 2009).

Numerous factors must be considered in planning the reintroduction of captive-bred populations, including disease risk, the potential effects of transport stress, changes in the genetic configuration of the captive population, and the propagation of a sustainable captive population (Mathews et al. 2006, Teix- eira et al. 2007, Ballou et al. 2010, Earnhardt 2010). In addition, behavior and complexities of social structure may affect reintroduction success. Although specific characteristics such as group size, feeding niche and activity patterns have been suggested to affect reintroduction success, many of these have not been tested experimentally to facilitate a better understanding of the factors critical to outcome (Stanley Price 1989, Mathews et al. 2005). In general, captiveborn individuals are less likely than wild-born conspecifics to survive and reproduce subsequent to release (Earnhardt 2010). Captive-bred individuals may suffer high mortality rates resulting from lack of anti-predator behavior or foraging skills or failure to integrate into social groups (Ralls \& Ballou 2013). Some species may be behaviorally flexible and, therefore, good candidates for pre-release training in behaviors well suited to survival in the wild (e.g. preparation for foraging, predator avoidance; Beck et al. 1991, Wells et al. 1998, Griffin et al. 2000).

The IUCN Reintroduction Specialist Group has provided guidelines for reintroductions and is a source of advice for those planning to reintroduce captive-bred taxa to the wild (www.iucnsscrsg.org). For example, the IUCN advises that the problems that caused the original wild population to go extinct should be greatly reduced or eliminated before captive-born individuals are reintroduced into an area.

\section{CONCLUSIONS}

We have described the difficulties that are encountered when attempting to breed small cetaceans in captivity, particularly species that have not been well-studied. We emphasize that any effort to capture and transport small cetaceans, especially an unfamiliar species and those in an estuarine or riverine environment, involves a substantial risk of injury and mortality to the animals. Unless well-experienced personnel conduct the operation, drowning, trauma, capture wounds (from nets or other capture gear), and bacterial and other infections related to capture damage and transport conditions are likely to remain a major cause of death among free-ranging cetaceans during and soon after capture (Walker 1975, Ridgway et al. 1989, Wang et al. 2000, Fisher \& Reeves 2005), especially in the riverine and tropical to sub-tropical habitat of many critically endangered small cetacean populations. Acclimation to captivity, which may be an especially acute challenge for riverdwelling species, including subpopulations of Irrawaddy dolphins Orcaella brevirostris, poses an ad- 
ditional risk of mortality. Some of the problems involving behavior, space requirements, and disease in these dolphins have been addressed over time. The techniques required to enable successful captive breeding of the majority of small cetaceans listed by the IUCN as Endangered or Critically Endangered have not been sufficiently developed for these species. In the future, development of these techniques should begin before a population is Critically Endangered.

The effects of removing individuals on the viability of the remaining wild population must be carefully weighed. This is a particularly important consideration when dealing with the small subpopulations of cetaceans listed by the IUCN as Critically Endangered (Fisher \& Reeves 2005), some of which have $<100$ individuals remaining. Removal of individuals from a cetacean population by live-capture is the population equivalent of lethal removal, with captured animals no longer available for reproduction. Removal of individuals from any of the Irrawaddy dolphin subpopulations, for instance, would pose a risk to a small population already susceptible to inbreeding depression and could diminish the overall fitness and potential for reproductive success of the wild population that is already exposed to other potential threats such as loss of habitat and entanglement in fishing nets. Thus, it is advisable to begin a captive breeding program well before the wild population becomes Critically Endangered.

Finally, ex situ conservation should incorporate in situ efforts as recommended by the IUCN (2012) and should consist of a systematically developed breeding program that includes planning for collection and housing of breeding populations, best implemented with guidance from collaboration among expert authorities. Major funding is required for a program to develop properly from the outset. In addition, a captive breeding program for any small cetacean not currently widely held in captivity is unlikely to be successful without a substantial research program combined with accredited facilities and staff. Many of the small cetacean species that are currently Endangered and Critically Endangered inhabit regions of underdeveloped nations, making achievement of logistical requirements incrementally more difficult. Also, we note that advancements in scientific knowledge and technology do not always translate into improved real-world practices. Even under the best of circumstances, developing a successful program takes many years of work. Assisted reproductive technologies, such as AI, are not a short-term solution to breeding enhancement. These techniques are spe- cies specific and usually take years of research to develop for a particular species. Existing research on cetacean reproductive biology and the use of ART for a few extensively studied odontocete species can provide insight and experience for use in other cetacean species, and may even be expected to advance some aspects of the use of ART in other species, but species-specific research will still be required before ART can be used on any new species.

Captive-bred small cetaceans should not be reintroduced into an area until the major threats to their survival have been eliminated. The development of successful techniques for the release of captive-bred individuals into viable habitat poses additional challenges. We conclude that the realities and risks involved indicate that, under current and foreseeable conditions, captive breeding has the potential to contribute to the conservation of only a very limited number of carefully selected small cetacean species. The main conservation measures needed to prevent the extinction of Critically Endangered small cetaceans are habitat preservation and the elimination of bycatch (e.g. Beasley et al. 2009, Kreb et al. 2010, Ross et al. 2010, 2011, Gerrodette \& Rojas-Bracho 2011).

\section{NOTE ADDED IN PROOFS}

Numerous studies have shown that the Yangtze finless porpoise Neophocaena asiaeorientalis asiaeorientalis is in decline. Mei et al. (2012) reported an accelerated decline of this subspecies based on life tables before and after 1993. Their individual-based Leslie matrix model predicted a high probability of extinction (86\%) within the next 100 yr. As a result, Mei et al. (2012) stated that the current rate of porpoise decline exceeds the threshold for IUCN Critically Endangered status (loss of $80 \%$ of abundance or higher within 3 generations), and recommended reclassifying the status of the Yangtze finless porpoise to Critically Endangered. Porpoises in the 2 semi-natural reserves at Tian'e-Zhou and Tongling Reserve have produced calves (Wang et al. 2006), but they cannot be considered self-sustaining populations. Only 1 calf has survived at IHB. Since it is generally believed that conditions in the Yangtze River will not improve in the foreseeable future (Zhou et al. 1998), it may never be possible to reintroduce these animals back into the Yangtze River. Thus, the only freshwater porpoise in the world will be functionally extinct, and then may soon join the ranks of other extinct Yangtze megafauna such as the baiji and the 7-m Chinese paddlefish Psephurus gladius. 
Acknowledgements. We thank J. D. Ballou (Smithsonian Conservation Biology Institute), J. M. Erhardt (Lincoln Park Zoo), and T. A. Jefferson (Southwest Fisheries Science Center), for providing us with copies of their papers prior to publication. G. Ryan (World Wildlife Fund) provided assistance with scientific literature from Vietnam. We thank G. Abel, (Ocean Park Hong Kong), T. A. Jefferson and G. Notarbartolo di Sciara (Tethys Research Institute), R. R. Reeves (Okapi Wildlife Associates), and 1 anonymous reviewer for their insightful comments on the manuscript. We acknowledge T. J. Ragen (US Marine Mammal Commission) for his valuable suggestions for ways of approaching the topics of conservation management and captive breeding. D. Losey (Southwest Fisheries Science Center), provided valuable assistance in obtaining scientific literature. Funding was provided by the US Marine Mammal Commission.

\section{LITERATURE CITED}

Andrabi SMH, Maxwell WMC (2007) A review on reproductive biotechnologies for conservation of endangered mammalian species. Anim Reprod Sci 99:223-243

AN Venezuela (Asamblea Nacional Venezuela) (2011a) AN presentará informe final sobre muerte de las toninas. Available at: www.asambleanacional.gob.ve/index.php? option=com_content $\&$ view $=$ article $\& i d=32139 \% 3$ Aanpresentara-informe-final-sobre-muerte-de-las-toninas\&catid=1\%3Alatest-news\&Itemid=246\&lang=es (accessed 29 February 2012)

AN Venezuela (Asamblea Nacional Venezuela) (2011b) Caso de las muertes de las toninas de Valencia será remitido al Ministerio Público. Available at: www.asamblea nacional.gov.ve/index.php?option=com_content\&view= article\&id=33267 \%3Acaso-de-las-muertes-de-las-toninas -de-valencia-sera-remitido-al-ministerio-publico-\&catid $=1 \% 3$ Alatest-news\&Itemid=246\&lang=es (accessed 29 February 2012)

Asper ED, Duffield DA, Dimeo-Edige N, Shell D (1990) Marine mammals in zoological parks in North America: 1990 census report. Int Zoo Yearb 29:179-187

Ballou JD, Lees C, Faust LJ, Long S, Lynch C, Bingaman L, Foose TJ (2010) Demographic and genetic management of captive populations. In: Kleiman DG, Thompson K, Kirk-Baer C (eds) Wild mammals in captivity, 2nd edn. University of Chicago Press, Chicago, IL, p 263-283

Beasley IL (2002) Monitoring of Thai captive cetacean facilities. Report to Whale and Dolphin Conservation Society (WDCS), WDCS, Adelaide

Beasley IL (2007) Conservation of the Irrawaddy dolphin, Orcaella brevirostris (Owen in Gray, 1866) in the Mekong River: biological and social considerations influencing management. PhD thesis, James Cook University, Townsville

Beasley IL, Davidson PJA (2007) Conservation status of marine mammals in Cambodian waters, including seven new cetacean records of occurrence. Aquat Mamm 33: 368-379

Beasley IL, Chooruk S, Piwpong N (2002) The status of the Irrawaddy dolphin, Orcaella brevirostris, in Songkhla Lake, southern Thailand. Raffles Bull Zool (Suppl 10): 75-83

Beasley IL, Marsh H, Jefferson TA, Arnold P (2009) Conserving dolphins in the Mekong River: the complex challenge of competing interests. In: Cambell IC (ed) The
Mekong: biophysical environment of an international river basin. Academic Press, London, p 365-389

Beck BB, Kleiman DG, Dietz JM, Castro I, Carvalho C, Martins A, Rettberg-Beck B (1991) Losses and reproduction in reintroduced golden lion tamarins (Leontopithecus rosalia). Dodo 27:50-61

Best RC, da Silva VMF (1993) Inia geoffrensis. Mamm Species 426:1-8

Bigg MA, Wolman AA (1975) Live-capture killer whale (Orcinus orca) fishery, British Columbia and Washington 1962-1973. J Fish Res Board Can 32:1213-1221

Boede EO (2005) Importancia de recopilar datos reproductivos en toninas del Orinoco (Inia geoffrensis humboldtiana) mantenidas en zoológicos y acuarios. Natura 127: $32-36$

Boede EO, Mujica-Jorquera E, de Boede N (1998) Management of the Amazon River dolphin Inia geoffrensis at Valencia Aquarium in Venezuela. Int Zoo Yearb 36: 214-222

> Bonar CJ, Boede EO, Hartmann MG, Lowenstein-Whaley J and others (2007) A retrospective study of pathologic findings in the Amazon and Orinoco River dolphin (Inia geoffrensis) in captivity. J Zoo Wildl Med 38:177-191

Bowkett AE (2009) Recent captive breeding proposals and the return of the ark concept to species conservation. Conserv Biol 23:773-776

Brando SICA (2010) Advances in husbandry and training in marine mammal care programs. Int J Comp Psychol 23: 777-791

Braulik GT, Smith BD, Chaundry AA (2004) Platanista gangetica ssp. minor. In: IUCN Red List of Threatened Species, Version 2011.1. IUCN, Gland. Available at: www.iucnredlist.org (accessed 16 July 2011)

Braulik GT, Reeves RR, Wang D, Ellis S, Wells RS, Dudgeon D (eds) (2005) Report of the workshop on conservation of the baiji and Yangtze finless porpoise. IUCN, Gland. Available at: www.iucn-csg.org/wp-content/uploads/ 2010/03/Brauliketal2005.pdf

Brook FM (2001) Ultrasonographic imaging of the reproductive organs of the female bottlenose dolphin, Tursiops truncatus aduncas. Reproduction 121:419-428

Brownell RL Jr (1984) Live-capture fisheries for small cetaceans in South American waters. Rep Int Whal Comm 34:747 (Abstract)

Brownell RL Jr (1989) Franciscana, Pontoporia blainvillei (Gervais and D'Orbigny, 1844). In: Ridgway SH, Harrison RJ (eds) Handbook of marine mammals, Vol 4. Academic Press, London, p 45-67

Bryden MM, Harrison RJ (1986) Gonads and reproduction. In: Bryden MM, Harrison RJ (eds) Research on dolphins. Clarendon Press, Oxford, p 149-159

Cade TJ (1988) Using science and technology to reestablish species lost in nature. In: Wilson EO (ed) Biodiversity. National Academy Press, Washington, DC, p 279-288

Caldwell MC, Caldwell DK (1972) The littlest ugly dolphin. Sea Front 18:24-29

Caldwell MC, Caldwell DK, Brill R (1989) Inia geoffrensis in captivity in the United States. Occas Pap IUCN SSC 3: 35-41

Chen P, Liu R (1989) Captive husbandry of the baiji, Lipotes vexillifer. Occas Pap IUCN SSC 3:146-149

Chen D, Hao Y, Zhao Q, Wang D (2006) Reproductive seasonality and maturity of male Neophocaena phocaenoides asiaeorientalis in captivity: a case study based on hormone evidence. Mar Freshw Behav Physiol 39:163-173 
Collet A (1984) Live-capture of cetaceans for European institutions. Rep Int Whaling Comm 34:603-607

> Comizzoli P, Mermillod P, Mauget R (2000) Reproductive biotechnologies for endangered mammalian species. Reprod Nutr Dev 40:493-504

Conway WG (2010) Buying time for wild animals with zoos. Zoo Biol 29:1-8

Cornell LH, Asper ED, Antrim JE, Osborn E, Gurevich VS (1977) Experiences of Sea World from 1963 to present with Tursiops species reproduction and some plans for the future. In: Ridgway SH, Benirschke K (eds) Breeding dolphins: present status, suggestions for the future. NTIS PB-273-673 US DOC, Washington, DC

Cornell LH, Asper ED, Antrim JE, Searles SS, Young WG, Goff T (1987) Progress report: results of a long-range captive breeding program for the bottlenosed dolphin, Tursiops truncatus and Tursiops truncatus gilli. Zoo Biol 6:41-54

Cowan DF, Curry BE (2008) Histopathology of the alarm reaction in small odontocetes. J Comp Pathol 139:24-33

Curry BE (1999) Stress in mammals: the potential influence of fishery-induced stress on dolphins in the eastern tropical Pacific Ocean. NOAA Tech Memo NMFS SWFSC260:1-121

da Silva VMF (1994) Aspects of the biology of the Amazonian dolphins genus Inia and Sotalia fluviatilis. $\mathrm{PhD}$ thesis, University of Cambridge, Cambridge

> DeMaster DP, Drevenak JK (1988) Survivorship patterns in three species of captive cetacean. Mar Mamm Sci 4: 297-311

Dima LD, Gache C (2004) Dolphins in captivity: realities and perspectives. Analele Ştiinţifice ale Universității, Al I Cuza, Iaşi, Biologie animal ă 100:413-418

DON (Department of the Navy) (2009) Swimmer interdiction system (SIS) final environmental impact statement, Appendix A. Navy Marine Mammal Program SSC San Diego, CA. Available at: www.nbkeis.gcsaic.com/ (accessed 23 June 2012)

Dudgeon D (2005) Last chance to see...: ex-situ conservation and the fate of the baiji. Aquat Conserv 15:105-108

Duffield DA, Wells RS (1991) Bottlenose dolphins: comparison of census data from bottlenose dolphins in captivity with a wild population. Int Mar Anim Trainers Assoc Soundings 1991:11-15

Earnhardt JM (2010) The role of captive populations in reintroduction programs. In: Kleiman DG, Thompson $\mathrm{K}$, Kirk-Baer C (eds) Wild mammals in captivity, 2nd edn. University of Chicago Press, Chicago, IL, p 268-280

Fisher SJ, Reeves RR (2005) The global trade in live cetaceans: implications for conservation. J Int Wildl Law Policy 8:315-340

Fleming AD, Yanagimachi R, Yanagimachi H (1981) Spermatazoa of the Atlantic bottlenose dolphin, Tursiops truncatus. J Reprod Fertil 63:509-514

Fripp M, Rokeach B, Robeck T, O'Brien J (2005) Objective assessment of a training program to facilitate semen collection from killer whales (Orcinus orca). Proc Int Mar Anim Trainers Assoc 33:41 (Abstract)

Furuta M, Tsukada O, Katakoa T, Kitamura S (1976) On the birth of finless porpoise, Neophocaena phocaenoides, in captivity. Dobutsuen Suizokukan Zasshi [J Jpn Assoc Zoos Aquariums] 18:43-48

Gerrodette T, Rojas-Bracho L (2011) Estimating the success of protected areas for the vaquita, Phocoena sinus. Mar Mamm Sci 27:101-125
Gerrodette T, Taylor BL, Swift R, Rankin S, Jaramillo-Legorreta AM, Rojas-Bracho L (2011) A combined visual and acoustic estimate of 2008 abundance, and change in abundance since 1997, for the vaquita, Phocoena sinus. Mar Mamm Sci 27:79-100

Goodrowe KL, Walker SL, Ryckman DP, Mastromanaco GF, Hay MA, Bateman HL, Waddell WT (2000) Piecing together the puzzle of carnivore reproduction. Anim Reprod Sci 60-61:389-403

Greenwood AG, Taylor DC (1985) Captive killer whales in Europe. Aquat Mamm 1:10-12

Griffin AS, Blumstein DT, Evans C (2000) Training captivebred or translocated animals to avoid predators. Conserv Biol 14:1317-1326

> Hao YJ, Chen DQ, Zhao QZ, Wang D (2007) Serum concentrations of gonadotropins and steroid hormones of $\mathrm{NeO}$ phocaena phocaenoides asiaeorientalis in middle and lower regions of the Yangtze River. Theriogenology 67: 673-680

Harrison RJ (1969) Reproduction and reproductive organs. In: Anderson HT (ed) The biology of marine mammals. Academic Press, New York, NY, p 253-348

Harrison RJ, McBreaty DA (1977) Ovarian appearances in captive dolphins (Tursiops \& Lagenorhynchus). Aquat Mamm 5:57-66

Harrison RJ, Ridgway SH (1971) Gonadal activity in some bottlenose dolphins (Tursiops truncatus). J Zool 165: 355-366

Harrison RJ, Brownell RL Jr, Boice RC (1972) Reproduction and gonadal appearances in some odontocetes. In: Harrison RJ (ed) Functional anatomy of marine mammals, Vol I. Academic Press, London, p 361-429

> Hooper DU, Chapin FS III, Ewel JJ, Hector A and others (2005) Effects of biodiversity on ecosystem functioning: a consensus of current knowledge. Ecol Monogr 75:3-35

Houser DS, Finneran JJ, Ridgway SH (2010) Research with navy marine mammals benefits animal care, conservation and biology. Int J Comp Psychol 23:249-268

Howard JG, Wildt DE (2009) Approaches and efficacy of artificial insemination in felids and mustelids. Theriogenology 71:130-148

Huffman WE (1970) Notes on the first captive conception and live birth of an Amazon dolphin in North America. Underwat Nat 6:9-11

Innes P, DeMaster DP, Rodriguez A, Crowder L (2005) Survival rates of marine mammals in captivity. In: Proc 16th biennial conference on the biology of marine mammals. Society for Marine Mammalogy, San Diego, CA, p 136 (Abstract)

IUCN (International Union for the Conservation of Nature) (2012) IUCN species survival commission guidelines on the use of ex situ management for species conservation. IUCN, Gland. Available at: www.iucn.org

Jefferson TA, Wang JY (2011) Revision of the taxonomy of finless porpoises (genus Neophocaena): the existence of two species. J Mar Anim Ecol 4:3-16

Jefferson TA, Karczmarski L, Kreb D, Laidre K and others (2008) Orcaella brevirostris (Mahakam River subpopulation). In: IUCN Red List of Threatened Species, Version 2011.1. IUCN, Gland. Available at: www.iucnredlist.org (accessed 16 July 2011)

Joseph B, Antrim J (2010) Special considerations for the care of marine mammals in captivity. In: Kleiman DG, Thompson $\mathrm{K}$, Kirk-Baer C (eds) Wild mammals in captivity, 2nd edn. University of Chicago Press, Chicago, IL, p 181-191 
Jule KR, Leaver LA, Lea SEG (2008) The effects of captive experience on reintroduction survival in carnivores: a review and analysis. Biol Conserv 141:355-363

Kasuya T, Tobayama T, Matsui S (1984) Review of live-capture of small cetaceans in Japan. Rep Int Whal Comm 34: 597-601

Keller KV (1986) Training Atlantic bottlenose dolphins (Tursiops truncatus) for artificial insemination. Proc Int Mar Anim Trainers Assoc 14:22-24

Kirby VL (1990) Endocrinology of marine mammals. In: Dierauf LA (ed) CRC handbook of marine mammal medicine: health, disease, and rehabilitation. CRC Press, Boca Raton, FL, p 303-351

Kirby VL, Ridgway SH (1984) Hormonal evidence of spontaneous ovulation in captive dolphins (Tursiops truncatus and Delphinus delphis). Rep Int Whal Comm Spec Issue 6:459-464

Kleiman DG (1996) Reintroduction programs. In: Kleiman DG, Allen ME, Thompson KV, Lumpkin S, Harris H (eds) Wild mammals in captivity: principles and techniques. University of Chicago Press, Chicago, IL, p 297-305

Kleiman DG, Rylands AB (2002) Lion tamarins: biology and conservation. Smithsonian Institution Press, Washington, DC

Kleiman DG, Thompson K, Kirk-Baer C (eds) (2010) Wild mammals in captivity, 2nd edn. University of Chicago Press, Chicago, IL

Knight AT, Cowling RM, Campbell BM (2006) An operational model for implementing conservation action. Conserv Biol 20:408-419

Kreb D, Syachraini B (2007) Review of status and conservation of Irrawaddy dolphins Orcaella brevirostris in the Mahakam River of East Kalimantan, Indonesia. Wildlife Conservation Society Working Paper 31:53-66

Kreb D, Reeves RR, Thomas PO, Braulik GT, Smith BD (2010) Establishing protected areas for Asian freshwater cetaceans: freshwater cetaceans as flagship species for integrated river conservation management. Final workshop report. Yayasan Konservasi RASI, Samarinda

Lasley BL, Anderson GB (1991) Where does biotechnology fit in captive breeding programs? Zoo Biol 10:195-196

Lee TM, Jetz W (2008) Future battlegrounds for conservation under global change. Proc R Soc Lond B Biol Sci 275: 1261-1270

Lees CM, Wilcken J (2009) Sustaining the ark: the challenges faced by zoos in maintaining viable populations. Int Zoo Yearb 43:6-18

Lenzi R (2000) Operant conditioning and ultrasound together at work to successfully condition voluntary urine collection. Proc Int Mar Anim Trainer Assoc 28:17 (Abstract)

Liu R, Wang K, Zhao Q (2002) Rearing of cetaceans in captivity in China. Acta Theriol Sin 22:130-135

Margules CR, Pressey RL (2000) Systematic conservation planning. Nature 405:243-253

Mathews F, Orros M, McLaren G, Gelling M, Foster R (2005) Keeping it on the ark: assessing the suitability of captivebred animals for release. Biol Conserv 121:569-577

Mathews F, Moro D, Strachan R, Gelling M, Buller N (2006) Zealand robins and saddlebacks with small numbers of founders. Health surveillance in wildlife reintroductions. Biol Conserv 131:338-347

McCosker JE (2007) The history of research at the California Academy of Science's Steinhart Aquarium and Department of Aquatic Biology. Proc Calif Acad Sci 58:171-195
Mei Z, Huang S-L, Hao Y, Turvey ST, Gong W, Wang D (2012) Accelerating population decline of Yangtze finless porpoise (Neophocaena asiaeorientalis asiaeorientalis). Biol Conserv 153:192-200

> Miller DL, Styer EL, Decker SJ, Robeck T (2002) Ultrastructure of the spermatozoa from three odontocetes: a killer whale (Orcinus orca), a Pacific white-sided dolphin (Lagenorhynchus obliquidens) and a beluga (Delphinapterus leucas). Anat Histol Embryol 31:158-168

Miyashita T, Sohn H, AN YR, Yoshida H (2005) Report of the workshop on finless porpoises in the western North Pacific. National Fisheries Research and Development Institute, Busan. Available at: www.jfa.maff.go.jp/e/ whale/w_study/pdf/20050526_research.pdf (accessed 26 October 2010)

Mohan RSL, Dey SC, Bairagi SP, Roy S (1997) On a survey of Ganges River dolphin Platanista gangetica of Brahmaputra River, Assam. J Bombay Nat Hist Soc 94:483-495

Monzón F, Corcuera J (1991) Franciscana Pontoporia blainvillei. In: Cappozzo HL, Junin M (eds) Estado de conservación de los mamíferos marinos del Atlantico Sudoccidental, Vol 138. Informes y Estudios del Programa de Mares Regionales del PNUMA, Nairobi, p 16-22

Morris PJ, Johnson WR, Pisani J, Bossart GD, Adams J, Reif JS, Fair PA (2011) Isolation of culturable microorganisms from free-ranging bottlenose dolphins (Tursiops truncatus) from the southeastern United States. Vet Microbiol 148:440-447

Nguyen NT, Cu DN, Trinh CLT, Phan TX and others (2010) Ket qua danh bat, thuan duo'ng, huan luyen ca heo ong su (Orcaella brevirostris) Vung Bien Kien Gian [Results on catching, domestication, and training of Irrawaddy dolphin (Orcaella brevirostris) in the Sea of Kien Giang Province]. In: Ve Sinh Thai Nhiet Doi, Giai Doan 20082010 [Scientific report on tropical ecology 2008-2010]. Vietnam-Russia Tropical Center, Ha Noi-Ho Chi, p 38-45 (in Vietnamese with English summary)

Nguyen NT, Mukhametov LM, Cu DN, Phan TX, Nguyen AT, Tran HTT, Tru'ong HB (2012a) Ket qua nghien cuu hoan thien cong nghe danh bat thuan du'ong thich nghi va van chuyen ca heo ong su Vung Bien Kien Giang, Viet Nam [Perfect survey result on technologies of fishing, taming, adapting and transporting of the Irrawaddy dolphins at the Kien Giang coastal areas, Vietnam]. In: On the 20th anniversary of the formation of the southern branch, Vietnam-Russia Tropical Center, 20.2.199220.2.2012. Vietnam-Russia Tropical Center, Ha Noi-Ho Chi, p 114-121 (in Vietnamese with English summary)

Nguyen TN, Trjnh CLT, Le THT, Alexander S and others (2012b) Ket qua thuan du'ong, huan luyen ca heo ong su (Orcaella brevirostris) bieu dien xiec tai trung tam thuan du'ong huan luyen ca heo dai nam-binh du'ong [The result of taming and training of Irrawaddy dolphin on the circus performance at Dai Nam Taming and Training Center, Binh Doung province]. In: On the 20th anniversary of the formation of the southern branch, VietnamRussia Tropical Center, 20.2.1992-20.2.2012. VietnamRussia Tropical Center, Ha Noi-Ho Chi, p 122-131 (in Vietnamese with English summary)

O'Brien JK, Robeck TR (2006) Development of sperm sexing and associated assisted reproductive technology for sex preselection of captive bottlenose dolphins (Tursiops truncatus). Reprod Fertil Dev 18:319-329

O'Brien JK, Robeck TR (2010a) The value of ex situ cetacean populations in understanding reproductive physiology 
and developing assisted reproductive technology for ex situ and in situ species management and conservation efforts. Int J Comp Psychol 23:227-248

O'Brien JK, Robeck TR (2010b) Preservation of beluga (Delphinapterus leucas) spermatozoa using a trehalosebased cryodiluent and directional freezing technology. Reprod Fertil Dev 22:653-663

> O'Brien JK, Steinman KJ, Schmitt T, Robeck TR (2008) Semen collection, characterisation and artificial insemination in the beluga (Delphinapterus leucas) using liquidstored spermatozoa. Reprod Fertil Dev 20:770-783

O'Brien JK, Steinman KJ, Robeck TR (2009) Application of sperm sorting and associated reproductive technology for wildlife management and conservation. Theriogenology 71:98-107

Olds RB (2003) Marine mammal systems in support of protection. In: SSC San Diego biennial review 2003: intelligence, surveillance, and reconnaissance. United States Department of the Navy, Washington, DC, p 131-135. Available at: www.spawar.navy.mil/sti/publications/pubs/ td/3155/4_Sectn3.pdf (accessed 23 June 2012)

Pelaez C (2010) Conoce a los toninas de Valencia. Codigo Venezuela: 22 October 2010. Available at: www.codigo venezuela.com/2010/10/ciencia/diversidad/conoce-a-las -toninas-de-valencia-antes-de-que-se-vayan (accessed 11 May 2011)

Perrin WF, Reilly SB (1984) Reproductive parameters of dolphins and small whales of the family Delphinidae. Rep Int Whal Comm Spec Issue 6:97-133

Perrin WF, Brownell WF Jr, Zhou K, Liu J (1989) Biology and conservation of the river dolphins. Occas Pap IUCN SSC 3:1-173

Perrin WF, Dolar MLL, Alava MNR (1996) Report of the workshop on the biology and conservation of small cetaceans and dugongs of Southeast Asia. UNEP(W)EAS WG.1/2, Bangkok

Perrin WF, Reeves RR, Dolar MLL, Jefferson TA, Marsh H, Wang JY, Estacion J (2005) Report of the second workshop on the biology and conservation of small cetaceans and dugongs of southeast Asia. CMS Technical Series Publication No. 9, UNEP-CMS Secretariat, Bonn

Pilleri G (1970) The capture and transport to Switzerland of two live Platanista gangetica from the Indus River. Invest Cetacea 2:61-68

Pilleri G (1972) Transport of a live Platanista indi from the Indus to Berne. Invest Cetacea 4:30-31

Pilleri G, Gihr M, Purves PE, Zbinden K, Kraus C (1976) On the behaviour, bioacoustics and functional morphology of the Indus River dolphin (Platanista indi Blyth, 1859). Invest Cetacea 6:11-141

Ralls K (1989) A semi-captive breeding program for the baiji, Lipotes vexillifer: genetic and demographic considerations. Biology and conservation of the river dolphins. Occas Pap IUCN SSC 3:150-156

Ralls K, Ballou JD (1992) Managing genetic diversity in captive breeding and reintroduction programs. In: McCabe RE(ed) Transactions of the 57th North American wildlife and natural resources conference. Charlotte, NC, p 263-282

Ralls K, Ballou JD (2004) Genetic status and management of the California condors. Condor 106:215-228

Ralls K, Ballou JD (2013) Captive breeding and reintroduction. In: Levin SA (ed) Encyclopedia of biodiversity, 2nd edn. Elsevier, Oxford
Ralls K, Meadows R (2001) Captive breeding and reintroduction. In: Levin SA (ed) Encyclopedia of biodiversity, Vol 1. Academic Press, San Diego, CA, p 599-607

Reddy M (1991) Cetacean transport standard operating procedure. Naval Ocean Systems Center Technical Manual 637, p 1-10

Reeves RR, Brownell RL Jr (1989) Susu Platanista gangetica (Roxburgh, 1801) and Platanista minor (Owen, 1853). In: Ridgway SH, Harrison RJ (eds) Handbook of marine mammals, Vol 4. Academic Press, London, p 69-99

Reeves RR, Gales NJ (2006) Realities of baiji conservation. Conserv Biol 20:626-628

Reeves RR, Mead JG (1999) Marine mammals in captivity. In: Twiss JR, Reeves RR (eds) Conservation and management of marine mammals. Smithsonian Institution Press, Washington, DC, p 412-436

Reeves RR, DeMaster DP, Hill CL, Leatherwood SL (1994) Survivorship of cetaceans at Ocean Park, Hong Kong, 1974-1994. Asian Mar Biol 11:107-124

Reeves RR, Wang JY, Leatherwood S (1997) The finless porpoise, Neophocaena phocaenoides (G. Cuvier, 1829): a summary of current knowledge and recommendations for conservation action. Asian Mar Biol 14:111-143

Ridgway SH, Norris KS, Cornell LH (1989) Some considerations for those wishing to propagate platanistoid dolphins. Occas Pap IUCN SSC 3:159-167

Robeck TR, Monfort SL (2006) Characterization of male killer whale (Orcinus orca) sexual maturation and reproductive seasonality. Theriogenology 66:242-250

Robeck TR, O'Brien JK (2004) Effect of cryopreservation methods and precryopreservation storage on bottlenose dolphin (Tursiops truncatus) spermatozoa. Biol Reprod 70:1340-1348

Robeck TR, Schneyer AL, McBain JF, Dalton LM, Walsh MT, Czekala N, Kraemer DC (1993) Analysis of urinary immunoreactive steroid metabolites and gonadotropins for characterization of the estrous cycle, breeding period, and seasonal estrous activity of captive killer whales (Orcinus orca). Zoo Biol 12:173-188

Robeck TR, Curry BE, McBain JF, Kraemer DC (1994) Reproductive biology of the bottlenose dolphin (Tursiops truncatus) and the potential application of advanced reproductive technologies. J Zoo Wildl Med 25:321-336

Robeck TR, Steinman KJ, Gearhart S, Reidarson TR, McBain JF, Monfort SL (2004) Reproductive physiology and development of artificial insemination technology in killer whales (Orcinus orca). Biol Reprod 71:650-660

Robeck TR, Monfort SL, Calle PP, Dunn JL and others (2005a) Reproduction, growth, and development in captive beluga (Delphinapterus leucas). Zoo Biol 24:29-49

> Robeck TR, Steinman KJ, Yoshioka M, Jensen E and others (2005b) Estrous cycle characterisation and artificial insemination using frozen-thawed spermatozoa in the bottlenose dolphin (Tursiops truncatus). Reproduction 129:659-674

Robeck TR, O'Brien JK, Odell DK (2008) Captive breeding. In: Perrin WF, Würsig B, Thewissen JGM (eds) Encyclopedia of marine mammals, 2nd edn. Academic Press, New York, NY, p 178-188

> Robeck TR, Steinman KJ, Greenwell M, Ramirez K and others (2009) Seasonality, estrous cycle characterization, estrus synchronization, semen cryopreservation, and artificial insemination in the Pacific white-sided dolphin (Lagenorhynchus obliquidens). Reproduction 138: 391-405 
Rojas B (2010) Artemis y Zeus son las únicas toninas de reemplazo. News Journal Carabobeño: 19 October 2010. Available at: www.el-carabobeno.com/ciudad/articulo/ 2427 (accessed 11 May 2011)

Rojas B (2011) Murió Helena, la cuarta tonina que pierde el acuario. News Journal Carabobeño: 14 April 2011. Available at: www.el-carabobeno.com/portada/articulo/ 12019/ (accessed 11 May 2011)

Ross PS, Dungan SZ, Hung SK, Jefferson TA and others (2010) Averting the baiji syndrome: conserving habitat for critically endangered dolphins in eastern Taiwan Strait. Aquat Conserv 20:685-694

$>$ Ross PS, Barlow J, Jefferson TA, Heckle BE and others (2011) Ten guiding principals for the delineation of habitat for endangered small cetaceans. Mar Policy 35: 483-488

Russello MA, Amato G (2007) On the horns of a dilemma: molecular approaches refine ex situ conservation in crisis. Mol Ecol 16:2405-2406

Sawyer-Steffan JE, Kirby VL, Gilmartin WC (1983) Progesterone and estrogens in the pregnant and non-pregnant dolphin, Tursiops truncatus, and the effects of induced ovulation. Biol Reprod 28:897-901

Schroeder JP (1990) Breeding bottlenose dolphins in captivity. In: Leatherwood S, Reeves RR (eds) The bottlenose dolphin. Academic Press, San Diego, CA, p 435-446

Schroeder JP, Keller KV (1989) Seasonality of serum testosterone levels and sperm density in Tursiops truncatus. J Exp Zool 249:316-321

Schroeder JP, Keller KV (1990) Artificial insemination of bottlenose dolphins. In: Leatherwood S, Reeves RR (eds) The bottlenose dolphin. Academic Press, San Diego, CA, p 447-460

Scott MD, Wells RS, Irvine AB (1990) A long-term study of bottlenose dolphins on the west coast of Florida. In: Leatherwood S, Reeves RR (eds) The bottlenose dolphin. Academic Press, San Diego, CA, p 235-244

Seddon PJ, Armstrong DP, Maloney RF (2007) Developing the science of reintroduction biology. Conserv Biol 21: 303-312

Small RJ, DeMaster DP (1995a) Acclimation to captivity: a quantitative estimate based on survival of bottlenose dolphins and California sea lions. Mar Mamm Sci 11: 510-519

Small RJ, DeMaster DP (1995b) Survival of five species of captive marine mammals. Mar Mamm Sci 11:209-226

Smith BD (2004) Orcaella brevirostris (Ayeyarwady River subpopulation). In: IUCN Red List of Threatened Species, Version 2011.1. IUCN, Gland. Available at: www. iucnredlist.org (accessed 16 July 2011)

Smith BD, Beasley I (2004a) Orcaella brevirostris (Malampaya Sound subpopulation). In: IUCN Red List of Threatened Species, Version 2011.1. IUCN, Gland. Available at: www.iucnredlist.org (accessed 16 July 2011)

Smith BD, Beasley I (2004b) Orcaella brevirostris (Mekong River subpopulation). In: IUCN Red List of Threatened Species, Version 2011.1. IUCN, Gland. Available at: www.iucnredlist.org (accessed 16 July 2011)

Smith BD, Beasley I (2004c) Orcaella brevirostris (Songkhla Lake subpopulation). In: IUCN Red List of Threatened Species, Version 2011.1. IUCN, Gland. Available at: www.iucnredlist.org (accessed 16 July 2011)

Smith BD, Thant UH, Lwin JM, Shaw CD (1997) Investigation of cetaceans in the Ayeyarwady River and northern coastal waters of Myanmar. Asian Mar Biol 14:173-194
Smith BD, Braulik G, Sinha RK (2004a) Platanista gangetica ssp. gangetica. In: IUCN Red List of Threatened Species, Version 2011.1. IUCN, Gland. Available at: www. iucnredlist.org (accessed 16 July 2011)

Smith BD, Beasley I, Buccat M, Calderon V and others (2004b) Status, ecology and conservation of Irrawaddy dolphins (Orcaella brevirostris) in Malampaya Sound, Palawan, Philippines. J Cetacean Res Manag 6:41-52

Snyder NFR, Derrickson SR, Beissinger SR, Wiley JW, Smith TB, Toone WD, Miller B (1996) Limitations of captive breeding in endangered species recovery. Conserv Biol 10:338-348

Snyder NFR, Derrickson SR, Beissinger SR, Wiley JW, Smith TB, Toone WD, Miller B (1997) Limitations of captive breeding: reply to Gippolitti and Carpaneto. Conserv Biol 11:808-810

Stacey PJ (1996) Natural history and conservation of Irrawaddy dolphins, Orcaella brevirostris, with special reference to the Mekong River, Laos PDR. MSc thesis, University of Victoria, Victoria

Stacey PJ, Arnold PA (1999) Orcaella brevirostris. Mamm Species 616:1-8

Stacey PJ, Leatherwood S (1997) The Irrawaddy dolphin Orcaella brevirostris: a summary of current knowledge and recommendations for conservation action. Asian Mar Biol 14:195-214

Stanley Price MR (1989) Animal reintroductions: the Arabian oryx in Oman. Cambridge University Press, Cambridge

Surovik LP, Lacinak CT, Tompkins CD, Scarpuzzi MR, Mairot JS, Andrews J, Robeck TR (2001) Training techniques utilized in the first successful artificial insemination of a cetacean. Proc Int Mar Anim Trainers Assoc 29: 19 (Abstract)

Sylvestre J (1985) Some observations on behaviour of two Orinoco dolphins (Inia geoffrensis humboltiana Pilleri and Gihr, 1977), in captivity, at Duisburg Zoo. Aquat Mamm 11:58-65

Tas'an A, Leatherwood S (1984) Cetaceans live-captured for Jaya Ancol Oceanarium, Djakarta, 1974-1982. Rep Int Whal Comm 34:485-489

Tas'an A, Irwandry A, Sumitro D, Hendrokusumo S (1980) Orcaella brevirostris (Gray, 1866) from Mahakam River. Report to Jaya Ancol Oceanarium, Jakarta

Tavolga MC, Essapian FS (1957) The behavior of the bottlenosed dolphin (Tursiops truncatus): mating, pregnancy, parturition and mother-infant behavior. Zoologica (NY) 42:11-31

Teixeira CP, De Azevedo CS, Mendl M, Cipreste CF, Young RJ (2007) Revisiting translocation and reintroduction programmes: the importance of considering stress. Anim Behav 73:1-13

> Thomassen R, Farstad W (2009) Artificial insemination in canids: a useful tool in breeding and conservation. Theriogenology 71:190-199

Tobayama T, Kamiya T (1989) Some data on the keeping of Inia geoffrensis in Kamagowa Sea World, Japan. Occas Pap IUCN SSC 3:42-45

Turvey S (2008) Witness to extinction: how we failed to save the Yangtze River dolphin. Oxford University Press, New York, NY

Turvey ST, Pitman RL, Taylor BL, Barlow J and others (2007) First human-caused extinction of a cetacean species? Biol Lett 3:537-540

> Urian KW, Duffield DA, Read AJ, Wells RS, Shell ED (1996) 
Seasonality of reproduction in bottlenose dolphins, Tursiops truncatus. J Mammal 77:394-403

Van Waerebeek K, Bamy IL, Jiddou AM, Sequeira M and others (2008) Indeterminate status of West African populations of inshore bottlenose dolphins Tursiops truncatus cautions against opportunistic live-capture schemes. Report to Fondation Internationale du Banc d'Arguin (FIBA), Morges. Available at: www.lafiba.org

Visconti P, Pressey R, Segan DB, Wintle BA (2010) Conservation planning with dynamic threats: the role of spatial design and priority setting for species' persistence. Biol Conserv 143:756-767

Walker WA (1975) Review of the live-capture fishery for smaller cetaceans taken in southern California waters for public display, 1966-73. J Fish Res Board Can 32: 1197-1211

Walker LA, Cornell L, Dahl KD, Czekala NM and others (1988) Urinary concentrations of ovarian steroid hormone metabolites and bioactive follicle-stimulating hormone in killer whales (Orcinus orchus) during ovarian cycles and pregnancy. Biol Reprod 39:1013-1020

Wang D (2009) Population status, threats and conservation of the Yangtze finless porpoise. Chin Sci Bull 54: 3473-3484

Wang D, Liu R, Zhang X, Yang J, Wei Z, Zhao Q, Wang X (2000) Status and conservation of the Yangtze finless porpoise. In: Reeves RR, Smith BD, Kasuya T (eds) Biology and conservation of freshwater cetaceans in Asia. Occas Pap IUCN SSC 23:81-84

Wang D, Hao YJ, Wang KX, Zhao QZ, Chen DQ, Wei Z, Zhang XF (2005) The first Yangtze finless porpoise successfully born in captivity. Environ Sci Pollut Res 12: $247-250$

Wang D, Zhang XF, Wang KX, Wei Z, Wursig B, Braulik GT, Ellis $S$ (2006) Conservation of the baiji: no simple solution. Conserv Biol 20:623-625

Wang D, Zhao Q, Hao Y, Zhou Y, Lei G (2010) Review of the conservation and protected areas established for the baiji, Lipotes vexilifer, and the finless porpoise, Neophocaena phocaenoides, in the Yangtze River, China. In: Kreb D, Reeves RR, Thomas PO, Braulik GT, Smith BD (eds) Establishing protected areas for Asian freshwater cetaceans: freshwater cetaceans as flagship species for integrated river conservation management. Final Workshop Report. Yayasan Konservasi RASI, Samarinda, p 62-72

Wei Z, Wand D, Zhang X, Wang K and others (2004) Observations on some sexual behavior of the Yangtze finless porpoise (Neophocaena phocaenoides asiaeorientalis) in captivity. Acta Theriol Sin 24:98-102

Wells RS, Bassos-Hull K, Norris KS (1998) Experimental return to the wild of two bottlenose dolphins. Mar Mamm Sci 14:51-71

Wells RS, Rhinehart HL, Hansen LJ, Sweeney JC and others (2004) Bottlenose dolphins as marine ecosystem sentinels: developing a health monitoring system. EcoHealth 1:246-254

Wells RS, Tornero V, Borrell A, Aguilar A and others (2005) Integrating life history and reproductive success data to examine potential relationships with organochlorine compounds for bottlenose dolphins (Tursiops truncatus) in Sarasota Bay, Florida. Sci Total Environ 349:106-119

Editorial responsibility: Helene Marsh,

Townsville, Queensland, Australia
Wildt DE (1989) Reproductive research in conservation biology: priorities and avenues for support. J Zoo Wildl Med 20:391-395

Wildt DE, Wemmer C (1999) Sex and wildlife: the role of reproductive science in conservation. Biodivers Conserv 8:965-976

Wildt DE, Schiewe MC, Schmidt PM, Goodrowe K, Philips JG, O'Brien S, Bach M (1986) Developing animal model systems for embryo technologies in rare and endangered wildlife. Theriogenology 25:33-51

Wildt DE, Monfort SL, Donogue AM, Johnston LA, Howard J (1992) Embryogenisis in conservation biology: or, how to make an endangered species embryo. Theriogenology 37:161-184

Wildt DE, Seal US, Rall WF (1993) Genetic resource banks and reproductive technology for wildlife conservation. In: Cloud JG, Thorgaard GH (eds) Genetic conservation of salmonid fishes. NATO ASI Series, Plenum Press, New York, NY, p 159-173

Wildt DE, Rall WF, Crister JK, Monfort SL, Seal US (1997) Genome resource banks: 'living collections' for biodiversity conservation. Bioscience 47:689-698

Wirawan N (1989) Protecting the Pesut (freshwater dolphin) in the Mahakam River of Kalimantan, Borneo. WWF Report WWF/IUCN Natural Resources Project 1687

Wisely SM, McDonald DB, Buskirk SW (2003) Evaluation of the species survival plan and captive breeding program for the black-footed ferret. Zoo Biol 22:287-298

Wu HP, Hao YJ, Yu XY, Zhao QZ and others (2010) Variation in sexual behaviors in a group of captive male Yangtze finless porpoises (Neophocaena phocaenoides asiaeorientalis): Motivated by physiological changes? Theriogenology 74:1467-1475

Yoshioka M, Mohri E, Tobayama T, Aida K, Hanyu I (1986) Annual changes in serum reproductive hormone levels in captive female bottle-nosed dolphins. Bull Jpn Soc Sci Fish 11:1939-1946

Yucra JM (2011) Acuario de Valencia no tiene las condiciones para albergar toninas. Notitarde: 6 June 2011. Available at: www.notitarde.com/notitarde/plantillas/ nota. aspx? idart $=1338701$ \&idcat $=9841 \&$ tipo $=2$ (accessed 29 February 2012)

Yuen QWH (2007) An assessment of reproductive development of the male Indo-Pacific dolphin, Tursiops aduncus, in captivity. PhD thesis, Hong Kong Polytechnic University Department of Health Technology and Informatics, Hong Kong

Yuen QWH, Brook FM, Kinoshita RE, Ying MTC (2009) Semen collection and ejaculate characteristics in the IndoPacific bottlenose dolphin (Tursiops aduncus). J Androl 30:432-439

Zagzebski K, Gulland F, Haulena M, Lander D and others (2006) Twenty-five years of rehabilitation of odontocetes stranded in central and northern California, 1977 to 2002. Aquat Mamm 32:334-345

> Zhang P, Sun N, Yao Z, Zhang X (2012) Historical and current records of aquarium cetaceans in china. Zoo Biol 31: 336-349

Zhou K, Sun, YJ, Gao AL, Würsig B (1998) Baiji (Lipotes vexillifer) in the lower Yangtze River: movements, numbers, threats and conservation needs. Aquat Mamm 24: $123-132$

Submitted: April 24, 2012; Accepted: September 2, 2012 Proofs received from author(s): December 17, 2012 